Part of Journal of Research of the National Bureau of Standards, Volume 26, January 1941

\title{
HYDROTHERMAL AND X-RAY STUDIES OF THE GARNET- HYDROGARNET SERIES AND THE RELATIONSHIP OF THE SERIES TO HYDRATION PRODUCTS OF PORTLAND CEMENT
}

\author{
By E. P. Flint, Howard F. McMurdie, and Lansing S. Wells
}

\section{ABSTRACT}

Isometric tricalcium aluminate hexahydrate, one of the well-established products of hydration of portland cement, forms complete solid solutions with the corresponding ferrite, $3 \mathrm{CaO} . \mathrm{Fe}_{2} \mathrm{O}_{3} \cdot 6 \mathrm{H}_{2} \mathrm{O}$, with grossularite garnet, $3 \mathrm{CaO} \cdot \mathrm{Al}_{2} \mathrm{O}_{3}$. $3 \mathrm{SiO}_{2}$, and with andradite garnet, $3 \mathrm{CaO} \cdot \mathrm{Fe}_{2} \mathrm{O}_{3} \cdot 3 \mathrm{SiO}_{2}$. Members of this solidsolution series were synthesized by hydrothermal methods, and X-ray determinations were made of their crystal structures. To the series belong: (1) The mineral plazolite, $3 \mathrm{CaO} \cdot \mathrm{Al}_{2} \mathrm{O}_{3} \cdot 2 \mathrm{SiO}_{2} \cdot 2 \mathrm{H}_{2} \mathrm{O}$, (2) the major product of hydration of the glass phase in portland cement clinker at elevated temperatures and pressures, and (3) one of the major products of hydration of tetracalcium aluminoferrite.

\section{CONTENTS}

Page.

I. Introduction _...

II. Hydrothermal study

1. Preliminary experiments

(a) Reaction of water at elevated temperatures with
glasses in the system $\mathrm{CaO}-2 \mathrm{CaO} . \mathrm{SiO}_{2}-5 \mathrm{CaO} \cdot 3 \mathrm{Al}_{2} \mathrm{O}_{3}$ $4 \mathrm{CaO} \cdot \mathrm{Al}_{2} \mathrm{O}_{3} \cdot \mathrm{Fe}_{2} \mathrm{O}_{3} \ldots \ldots$

(b) Preparation of calcium aluminoferrite hydrates .... 15

(c) Decomposition temperatures of silica-containing calcium aluminoferrite hydrates

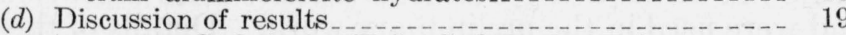

2. Preparation of $3 \mathrm{CaO} \cdot \mathrm{Al}_{2} \mathrm{O}_{3} \cdot 6 \mathrm{H}_{2} \mathrm{O}-3 \mathrm{CaO} \cdot \mathrm{Fe}_{2} \mathrm{O}_{3} \cdot 6 \mathrm{H}_{2} \mathrm{O}-\mathrm{g}$ ros s u larite-andradite solid solutions

(a) Procedure

(b) Results of analytical and microscopical determina-

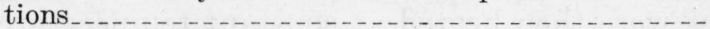

3. Substitution of other oxides for $\mathrm{CaO}, \mathrm{Al}_{2} \mathrm{O}_{3}$, and $\mathrm{Fe}_{2} \mathrm{O}_{3}$ in the solid-solution series _._.

4. Products of reaction of water with tetracalcium aluminoferrite $\quad 23$

5 . Bearing of results on products of hydration of portland cement -25

6. Summary of hydrothermal study

III. X-ray structure studies

1. Introduction and methods

2. Structure of $3 \mathrm{CaO} \cdot \mathrm{Al}_{2} \mathrm{O}_{3} \cdot 6 \mathrm{H}_{2} \mathrm{O}_{2}$

3. The series $3 \mathrm{CaO} .(\mathrm{Al}, \mathrm{Fe})_{2} \mathrm{O}_{3} \cdot 3 \mathrm{SiO}_{2}-3 \mathrm{CaO} \cdot(\mathrm{Al}, \mathrm{Fe})_{2} \mathrm{O}_{3} \cdot 6 \mathrm{H}_{2} \mathrm{O}_{-}-{ }_{2} 29$

4. Occurrence of the series as natural minerals

5. Summary of X-ray study

IV. References 


\section{INTRODUCTION}

Although rather extensive investigations have been made on the reactions of the crystalline constituents of portland cement with water, no such study has been reported with respect to the glass phase in cement clinker. In the course of some experiments related to this problem, on the reaction of water at elevated temperatures and pressures with glasses in the quaternary system $\mathrm{CaO}-\mathrm{Al}_{2} \mathrm{O}_{3}-\mathrm{Fe}_{2} \mathrm{O}_{3}-\mathrm{SiO}_{2}$, certain results were obtained which led to an investigation of possible solid solution relationships between the isometric tricalcium aluminate hexahydrate and the isometric tricalcium ferrite hexahydrate recently discovered by Eiger [1]. ${ }^{1}$ The existence of such solid solutions was confirmed, and it was found that their stability was considerably influenced by the presence of silica.

An extension of the study revealed that silica could replace waterin both $3 \mathrm{CaO} \cdot \mathrm{Al}_{2} \mathrm{O}_{3} \cdot 6 \mathrm{H}_{2} \mathrm{O}$ and $3 \mathrm{CaO} \cdot \mathrm{Fe}_{2} \mathrm{O}_{3} \cdot 6 \mathrm{H}_{2} \mathrm{O}$, and that the end products of these substitutions are grossularite garnet, $3 \mathrm{CaO} \cdot \mathrm{Al}_{2} \mathrm{O}_{3} \cdot 3 \mathrm{SiO}_{2}$, and andradite garnet, $3 \mathrm{CaO} \cdot \mathrm{Fe}_{2} \mathrm{O}_{3} .3 \mathrm{SiO}_{2}$, respectively. Complete solid solutions exist between each of these compounds and the other three. The hydrous members of the series may be termed "hydrogarnets" to indicate their relationship to the naturally occurring garnets.

This investigation is presented in two parts. The first deals with the synthesis of various garnets and hydrogarnets, and the second deals with their structures as revealed by $\mathrm{X}$-ray data.

\section{HYDROTHERMAL STUDY}

By E. P. Flint and Lansing S. Wells

\section{PRELIMINARY EXPERIMENTS}

(a) REACTION OF WATER AT ELEVATED TEMPERATURES WITH GLASSES IN THE SYSTEM CaO-2CaO.SiO $2-5 \mathrm{CaO}_{2} 3 \mathrm{Al}_{2} \mathrm{O}_{3}-4 \mathrm{CaO} . \mathrm{Al}_{2} \mathrm{O}_{3} \cdot \mathrm{Fe}_{2} \mathrm{O}_{3}$

Small quantities of glasses representative of the composition of various liquid phases at $1,400^{\circ} \mathrm{C}$ in the system $\mathrm{CaO}-2 \mathrm{CaO}$. $\mathrm{SiO}_{2}-5 \mathrm{CaO}$. $3 \mathrm{Al}_{2} \mathrm{O}_{3}-4 \mathrm{CaO} \cdot \mathrm{Al}_{2} \mathrm{O}_{3} \cdot \mathrm{Fe}_{2} \mathrm{O}_{3}$ were available from a previous investigation. and were used in the preliminary work. Details of the method of preparing these glasses have been given by Lerch and Brownmiller [2]. Half-gram quantities of the finely powdered glasses with $10 \mathrm{ml}$ of $\mathrm{CO}_{2}$-free water were placed in steel bombs of 40-ml capacity, and the bombs were then heated at constant temperature ( \pm 5 degrees $C)$ in electric furnaces for several days. The apparatus and procedure were the same as those described in a previous publication [3]. After the completion of the heating period, the products were removed from the bombs, washed with alcohol and ether, and dried over calcium chloride in a desiccator. The results obtained from treatment of glasses of various compositions are listed in table 1 .

1 Numbers in brackets indicate the literature references at the end of this paper. 
TABLE 1.-Results of treating $\mathrm{CaO}-\mathrm{Al}_{2} \mathrm{O}_{3}-\mathrm{Fe}_{2} \mathrm{O}_{3}-\mathrm{SiO}_{2}$ glasses with water at elevated temperatures

\begin{tabular}{|c|c|c|c|c|c|c|c|}
\hline \multirow{2}{*}{$\begin{array}{c}\text { Experi- } \\
\text { ment } \\
\text { number }\end{array}$} & \multicolumn{4}{|c|}{ Oxide composition of the glasses } & \multirow{2}{*}{$\begin{array}{l}\text { Tem- } \\
\text { pera- } \\
\text { ture }\end{array}$} & \multirow{2}{*}{ Time } & \multirow{2}{*}{ Crystalline phases in product } \\
\hline & $\mathrm{CaO}$ & $\mathrm{Al}_{2} \mathrm{O}_{3}$ & $\mathrm{Fe}_{2} \mathrm{O}_{3}$ & $\mathrm{SiO}_{2}$ & & & \\
\hline 1 a & $\begin{array}{l}\% \\
58.3\end{array}$ & $\begin{array}{l}\% \\
33.0\end{array}$ & $\begin{array}{l}\% \\
0.0\end{array}$ & $\begin{array}{l}\% \\
8.7\end{array}$ & ${ }^{\circ}{ }_{250}$ & $\begin{array}{r}\text { Days } \\
6\end{array}$ & $90 \%$ isometric phase, $n=1.615$. \\
\hline & 56.7 & 30.3 & 5.0 & 8. 0 & 200 & 5 & $\begin{array}{l}80 \% \text { isometric phase, } n=1.625 \text {; scarce hema- } \\
\text { tite; no } \mathrm{Ca}(\mathrm{OH})\end{array}$ \\
\hline $3 \mathrm{~b}$ & 54.8 & 22.7 & 16. 5 & 6.0 & 200 & 4 & $\begin{array}{l}80 \% \text { isometric phase, } n=1.655 ; 5 \text { to } 10 \% \\
\text { hematite; } 5 \% \mathrm{Ca}(\mathrm{OH})_{2} \text {. }\end{array}$ \\
\hline 4. & 53.1 & 17.8 & 23.7 & 5.5 & 200 & 5 & $70 \%$ isometric phase; $n=1.655 ; 10$ to $15 \%$ \\
\hline 5 & 58.1 & 23.5 & 18. 4 & 0.0 & 200 & 9 & 30 to $40 \%$ isometric phase, $n=1.625$. \\
\hline & 56.3 & 17.0 & 26.7 & .0 & 200 & 7 & 20 to $30 \%$ isometric phase, $n=1.65$. \\
\hline & 54.5 & 11.0 & 34.4 & .0 & 175 & 9 & 20 to $30 \%$ isometric phase, $n=1.67$. \\
\hline
\end{tabular}

a Composition of liquid at invariant point $3 \mathrm{CaO} . \mathrm{Al}_{2} \mathrm{O}_{3}, 2 \mathrm{CaO} . \mathrm{SiO}_{2}, 3 \mathrm{CaO} \cdot \mathrm{SiO}_{2}$ in system $\mathrm{CaO}-\mathrm{Al}_{2} \mathrm{O}_{3}-\mathrm{SiO}_{2}$.

b Composition of liquid at quaternary eutectic $3 \mathrm{CaO} . \mathrm{SiO}_{2}, 2 \mathrm{CaO} . \mathrm{SiO}_{2}, 3 \mathrm{CaO} . \mathrm{Al}_{2} \mathrm{O}_{3}, 4 \mathrm{CaO} . \mathrm{Al}_{2} \mathrm{O}_{3} . \mathrm{Fe}_{2} \mathrm{O}_{3}$ in system $\mathrm{CaO}-\mathrm{Al}_{2} \mathrm{O}_{3}-\mathrm{Fe}_{2} \mathrm{O}_{3}-\mathrm{SiO}_{2}$.

The predominant phase obtained in experiments 1 to 4 consisted of isotropic crystals, frequently of rectangular outline but often appearing to retain the shapes of the original glass fragments. These aggregates exhibited closely spaced longitudinal striations. The index of refraction of the isotropic phase increased from 1.615, in the product from the $\mathrm{Fe}_{2} \mathrm{O}_{3}$-free glass, to 1.655 , in the product of experiment 4 . This change in refractive index was accompanied by a deepened yellow color of the crystals.

Because the refractive indices of this phase were intermediate between those of $3 \mathrm{CaO} \cdot \mathrm{Al}_{2} \mathrm{O}_{3} \cdot 6 \mathrm{H}_{2} \mathrm{O}, n=1.605$, and the 1somorphous compound $3 \mathrm{CaO} \cdot \mathrm{Fe}_{2} \mathrm{O}_{3} \cdot 6 \mathrm{H}_{2} \mathrm{O}, n=1.710$, it seemed probable that the crystals might represent solid solutions of these two compounds. Experiments 5, 6, and 7 record attempts to prepare members of such a solid-solution series. The glasses used contained $\mathrm{CaO}, \mathrm{Al}_{2} \mathrm{O}_{3}$, and $\mathrm{Fe}_{2} \mathrm{O}_{3}$ in the molar proportions $9: 2: 1,6: 1: 1$, and $9: 1: 2$. If but one phase were formed in the hydration of these glasses, the resulting products would be intermediate between $3 \mathrm{CaO} \cdot \mathrm{Al}_{2} \mathrm{O}_{3} \cdot 6 \mathrm{H}_{2} \mathrm{O}$ and $3 \mathrm{CaO} \cdot \mathrm{Fe}_{2} \mathrm{O}_{3} \cdot 6 \mathrm{H}_{2} \mathrm{O}$ in composition. Similar treatments in the bombs gave much smaller amounts of the isometric phase than had been obtained from the glasses containing silica. The balance of the products consisted of hematite, calcium hydroxide, and considerable poorly crystallized unidentified material. Apparently the presence of silica in the glasses of experiments 1 to 4 helped to stabilize the isometric phase.

Other $\mathrm{CaO}-\mathrm{Al}_{2} \mathrm{O}_{3}-\mathrm{Fe}_{2} \mathrm{O}_{3}$ glasses were prepared, using $\mathrm{B}_{2} \mathrm{O}_{3}$ as a flux, but on hydration these gave a highly birefringent material as the primary phase and none of the isometric crystals. Another method of preparation therefore was sought.

\section{(b) PREPARATION OF CALCIUM ALUMINOFERRITE HYDRATES}

Eiger [1] prepared $3 \mathrm{CaO} \cdot \mathrm{Fe}_{2} \mathrm{O}_{3} \cdot 6 \mathrm{H}_{2} \mathrm{O}$ by treating colloidal hydrated ferric oxide with a lime solution for 6 weeks, and he obtained in this way a mixture of isometric crystals of refractive index 1.710 and hexagonal crystals of indices 1.61 to 1.65 . The isometric $3 \mathrm{CaO}$. $\mathrm{Al}_{2} \mathrm{O}_{3} .6 \mathrm{H}_{2} \mathrm{O}$ may also be obtained at room temperature, but is like- 
wise usually accompanied by considerable amounts of the hexagonal form of hydrated calcium aluminate [4], unless sufficient time is allowed for transformation of the hexagonal to the isometric form, a process that usually requires several months. A product made in this way is shown in figure 1. However, if the preparation is carried out at higher temperatures $\left(60^{\circ}\right.$ to $100^{\circ} \mathrm{C}$.), the isometric aluminate crystallizes without any of the hexagonal form [5]. Since, in this study, preparations were desired which would be free from hexagonal ferrite or aluminate, a method was adopted wherein crystallization was brought about at $100^{\circ} \mathrm{C}$.

The procedure involved the very slow addition of a dilute acidified solution of iron and aluminum chlorides to a large volume of boiling calcium hydroxide solution. Samples of iron and aluminum of high purity and ignited reagent quality calcium carbonate were the original materials. Sufficient iron and aluminum were used in all cases to give $3 \mathrm{~g}$ of each hydrate. In each experiment the required quantities of the two metals were placed in a small beaker, dissolved in 10 to 15 $\mathrm{ml}$ of $6 \mathrm{~N} \mathrm{HCl}$, and any ferrous iron was oxidized by the addition of hydrogen peroxide. After evaporation to dryness to remove excess $\mathrm{HCl}$, the mixture of ferric and aluminum chlorides was taken up in $100 \mathrm{ml}$ of $\mathrm{CO}_{2}$-free water containing $2 \mathrm{ml}$ of concentrated $\mathrm{HCl}$. This solution was then added over an interval of 8 to 10 hours to $5 \frac{1}{2}$ liters of boiling lime suspension ( $1.15 \mathrm{~g}$ of $\mathrm{CaO}$ per liter). The lime suspension was contained in a 6 -liter flask fitted with a rubber stopper carrying a reflux condenser and a dropping funnel with a constricted tip. Protection from atmospheric $\mathrm{CO}_{2}$ was provided by soda-lime tubes. The solution in the flask was kept boiling vigorously on a hot plate. It was found necessary to add the $\mathrm{FeCl}_{3}-\mathrm{AlCl}_{3}$ solution in very small droplets at the rate of only 10 to $15 \mathrm{ml}$ per hour in order to prevent the precipitation of ferric hydroxide by the lime solution. After all of the chloride solution had been added, boiling was continued for an additional half hour. The resulting mixture was cooled to room temperature and agitated until any calcium hydroxide crystals present had been dissolved. The product was then filtered off, washed with alcohol and ether, and dried overnight in a calcium chloride desiccator. Chemical analyses and index of refraction measurements are given in table 2 .

TABLE 2.-Compositions and indices of refraction of hydrated calcium aluminoferrite solid solutions

\begin{tabular}{|c|c|c|c|c|c|c|c|c|c|c|c|c|}
\hline \multirow{2}{*}{$\begin{array}{c}\text { Sample } \\
\text { num- } \\
\text { ber }\end{array}$} & \multicolumn{5}{|c|}{ Composition by analysis } & \multicolumn{6}{|c|}{ Molar ratios of preparations } & \multirow{2}{*}{$\begin{array}{c}\text { Index } \\
\text { of re- } \\
\text { fraction }\end{array}$} \\
\hline & $\mathrm{CaO}$ & $\mathrm{Al}_{2} \mathrm{O}_{3}$ & $\mathrm{Fe}_{2} \mathrm{O}_{3}$ & $\mathrm{SiO}_{2}$ & $\mathrm{H}_{2} \mathrm{O}$ & $\mathrm{CaO}$ & $\mathrm{Al}_{2} \mathrm{O}_{3}$ & $\mathrm{Fe}_{2} \mathrm{O}_{3}$ & $\mathrm{SiO}_{2}$ & $\mathrm{H}_{2} \mathrm{O}$ & $\mathrm{H}_{2} \mathrm{O}+2 \mathrm{SiO}_{2}$ & \\
\hline 5 & $\begin{array}{c}\% \\
44.35 \\
43.12 \\
41.56 \\
40.72 \\
38.52\end{array}$ & $\begin{array}{r}\% \\
26.38 \\
24.06 \\
15.63 \\
11.85 \\
7.52\end{array}$ & $\begin{array}{r}\% \\
2.37 \\
12.83 \\
18.36 \\
26.30\end{array}$ & $\begin{array}{c}\% \\
1.06 \\
6.28 \\
5.36 \\
6.37 \\
3.34\end{array}$ & $\begin{array}{c}\% \\
27.81 \\
23.97 \\
24.56 \\
22.52 \\
23.78\end{array}$ & $\begin{array}{l}3.06 \\
3.07 \\
3.18 \\
3.15 \\
2.88\end{array}$ & $\begin{array}{r}0.94 \\
.66 \\
.50 \\
.31\end{array}$ & $\begin{array}{r}1.00 \\
0.06 \\
.34 \\
.50 \\
.69\end{array}$ & $\begin{array}{r}0.07 \\
.41 \\
.38 \\
.46 \\
.23\end{array}$ & $\begin{array}{l}\text { 5. } 97 \\
5.31 \\
5.83 \\
5.42 \\
5.52\end{array}$ & $\begin{array}{l}6.11 \\
6.13 \\
6.59 \\
6.34 \\
5.98\end{array}$ & $\begin{array}{l}1.607 \\
1.618 \\
1.642 \\
1.665 \\
1.675\end{array}$ \\
\hline $\begin{array}{l}8 \\
9 \\
90 \ldots\end{array}$ & $\begin{array}{l}40.22 \\
38.28 \\
38.50 \\
38.19 \\
40.03\end{array}$ & $\begin{array}{r}7.97 \\
\end{array}$ & $\begin{array}{l}24.65 \\
35.55 \\
35.19 \\
35.27 \\
32.16\end{array}$ & $\begin{array}{l}4.16 \\
5.13 \\
5.54 \\
7.11 \\
6.34\end{array}$ & $\begin{array}{l}23.04 \\
20.56 \\
20.70 \\
19.79 \\
21.83\end{array}$ & $\begin{array}{l}3.09 \\
3.07 \\
3.12 \\
3.08 \\
3.54\end{array}$ & .34 & $\begin{array}{r}.66 \\
1.00 \\
1.00 \\
1.00 \\
1.00\end{array}$ & $\begin{array}{l}.30 \\
.38 \\
.42 \\
.54 \\
.52\end{array}$ & $\begin{array}{l}5.50 \\
5.24 \\
5.34 \\
4.97 \\
6.01\end{array}$ & $\begin{array}{l}6.10 \\
6.00 \\
6.18 \\
6.05 \\
7.05\end{array}$ & $\begin{array}{l}1.678 \\
1.720 \\
1.723 \\
1.730 \\
1.710\end{array}$ \\
\hline
\end{tabular}




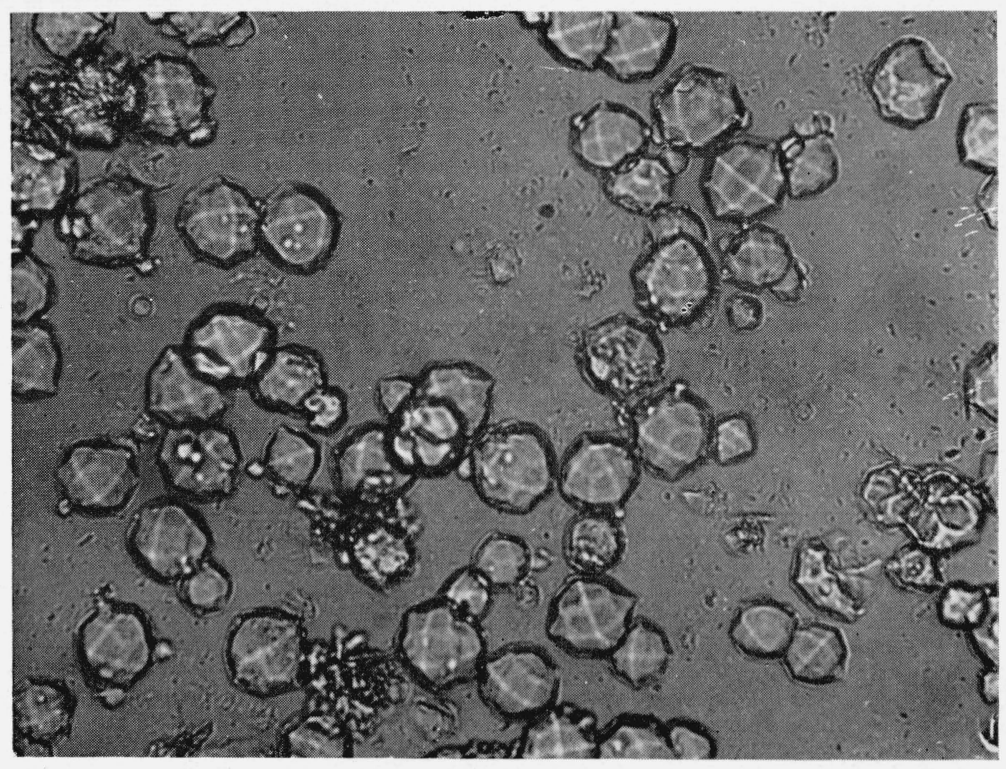

Figure 1.-Icositetrahedral form of $3 \mathrm{CaO} \cdot \mathrm{Al}_{2} \mathrm{O}_{3} \cdot 6 \mathrm{H}_{2} \mathrm{O}$. Magnification $\times 250$.

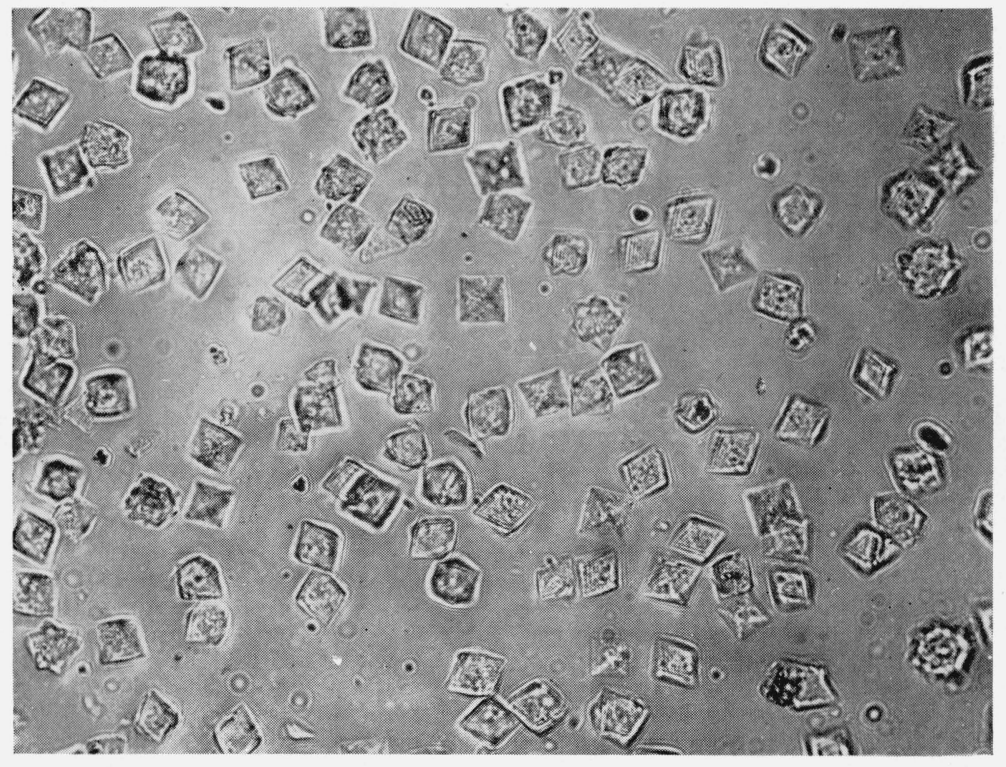

Figure 2.-Preparation 2, table 2.

Magnification $\times 400$. 


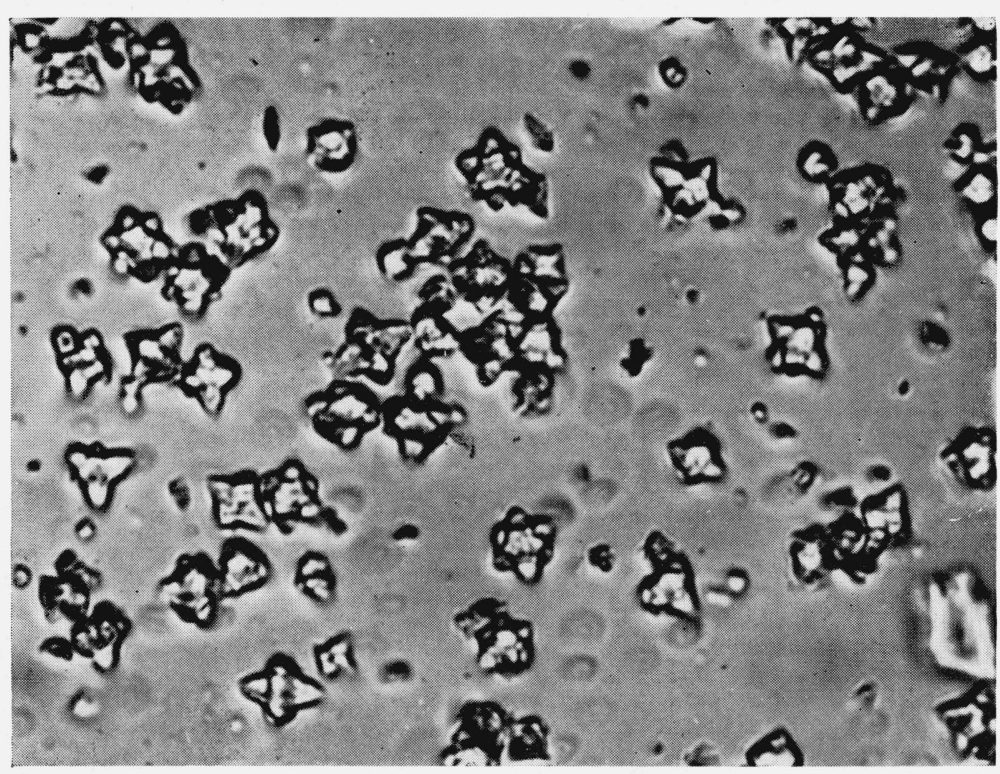

Figure 3.-Preparation $\%$, table 2.

Magnification $\times 1300$. 
Microscopical examinations of the products indicated a purity of 95 percent or better, the preparations being made up of well-developed octahedral crystals. None of the other crystal habits reported by other writers (cubes, rhombic dodecahedrons, icositetrahedrons, etc.) of $3 \mathrm{CaO} \cdot \mathrm{Al}_{2} \mathrm{O}_{3} \cdot 6 \mathrm{H}_{2} \mathrm{O}$ was observed. A photomicrograph of a typical preparation is shown in figure 2. The preparations toward the aluminate end of the series gave the best developed crystals, and the crystal size decreased as their iron content increased. Toward the ferrite end of the series the octahedral faces of the crystals were not completely developed, and exhibited the cross-like appearance shown in figure 3 . The iron-containing products were of a light-yellow color.

Although no silica or hydrated calcium silicate could be detected microscopically in the products, the analyses in table 2 show each sample to be contaminated by 1 to 7 percent of $\mathrm{SiO}_{2}$. Furthermore, the water contents $\left(\mathrm{H}_{2} \mathrm{O} / \mathrm{R}_{2} \mathrm{O}_{3}\right)$ of the preparations are consistently lower than the theoretical value $\left(\mathrm{H}_{2} \mathrm{O} / \mathrm{R}_{2} \mathrm{O}_{3}=6\right)$. However, if the molar ratio of $\left(\mathrm{H}_{2} \mathrm{O}+2 \mathrm{SiO}_{2}\right) / \mathrm{R}_{2} \mathrm{O}_{3}$ is calculated, values in better accord with theory are obtained, as may be seen in the table. It will be noted also that all but one of the silica-containing $3 \mathrm{CaO} \cdot \mathrm{Fe}_{2} \mathrm{O}_{3} \cdot 6 \mathrm{H}_{2} \mathrm{O}$ preparations have refractive indices slightly higher than the 1.710 reported by Eiger [1].

Various expedients were tried in attempts to eliminate the contamination by silica. Experiments were made using copper and iron reaction vessels, but the products thereby obtained were all badly contaminated with hydrous iron oxide, no matter how slowly the ironcontaining solution was added. The same condition resulted when a silver-lined glass flask was used. Thus, as in the case of the treatment of the $\mathrm{CaO}-\mathrm{Al}_{2} \mathrm{O}_{3}-\mathrm{Fe}_{2} \mathrm{O}_{3}-\mathrm{SiO}_{2}$ glasses with water, it is indicated that the presence of silica helps to stabilize the calcium aluminoferrite hydrates.

Glass containers of various compositions were tried, but none was found having complete resistance to lime solution. Other experiments were made wherein the reaction period in the glass flask was reduced to 3 hours. This could be accomplished without precipitation of ferric hydroxide if the iron-aluminum chloride solution was added to a rather heavy lime suspension containing about $10 \mathrm{~g}$ of $\mathrm{CaO}$ in excess of that used previously. After cooling the mixture to room temperature, the excess lime was removed by diluting with sufficient $\mathrm{CO}_{2}$-free water. However, it was found that the preparations were not improved by this treatment, as they still contained 4 to 5 percent of silica.

One preparation (No. 10 , table 2 ) of the compound $3 \mathrm{CaO} \cdot \mathrm{Fe}_{2} \mathrm{O}_{3} \cdot 6 \mathrm{H}_{2} \mathrm{O}$ was attempted in a container of dense unglazed porcelain. Analysis showed 6.34 percent of silica, and the composition corresponded to $3.54 \mathrm{CaO}: 1.00 \mathrm{Fe}_{2} \mathrm{O}_{3}: 0.52 \mathrm{SiO}_{2}: 6.01 \mathrm{H}_{2} \mathrm{O}$. This preparation differs from the others listed in table 2 in showing considerable contamination by fine-grained material of low birefringence, which may have been hydrated calcium silicate. However, it is included here because a determination of the unit-cube size of the isometric constituent in Section III of this paper showed very close agreement with the estimated theoretical unit-cell value of $3 \mathrm{CaO} \cdot \mathrm{Fe}_{2} \mathrm{O}_{3} \cdot 6 \mathrm{H}_{2} \mathrm{O}$. 
When ferric chloride solution is added to limewater at room temperature a calcium chloroferrite, $3 \mathrm{CaO} \cdot \mathrm{Fe}_{2} \mathrm{O}_{3} \cdot \mathrm{CaCl}_{2} \cdot 10 \mathrm{H}_{2} \mathrm{O}$, is formed. At room temperature this compound goes over slowly to $3 \mathrm{CaO}_{2} \mathrm{Fe}_{2} \mathrm{O}_{3}$. $6 \mathrm{H}_{2} \mathrm{O}$. Thus, a chloroferrite precipitate allowed to stand at room temperature for 95 days in contact with its solution was about 50 percent converted to the isometric compound. This sample contained 0.83 percent of $\mathrm{SiO}_{2}$. Another chloroferrite preparation, which was filtered shortly after precipitation, and hence contained negligible silica, was placed in contact with dilute lime solution $(0.626 \mathrm{~g}$ of $\mathrm{CaO} /$ liter $)$ and maintained at $60^{\circ} \mathrm{C}$ with frequent shaking. After 2 weeks, it was completely transformed to the isometric compound. The product was found to contain 6.85 percent of $\mathrm{SiO}_{2}$ taken up from the glass container during this period.

(c) DËCOMPOSITION TEMPERATURES OF SILICA-CONTAINING CALCIUM ALUMINO. FERRITE HYDRATES

To determine the temperatures at which members of the series break down in contact with solution, 0.2 - to $0.3-\mathrm{g}$ samples of some of the preparations listed in table 2 were heated in the bombs with $10 \mathrm{ml}$ of a dilute lime solution $(0.2 \mathrm{~g}$ of $\mathrm{CaO}$ per liter) at various temperatures. The decomposition temperature was assumed to be that above which

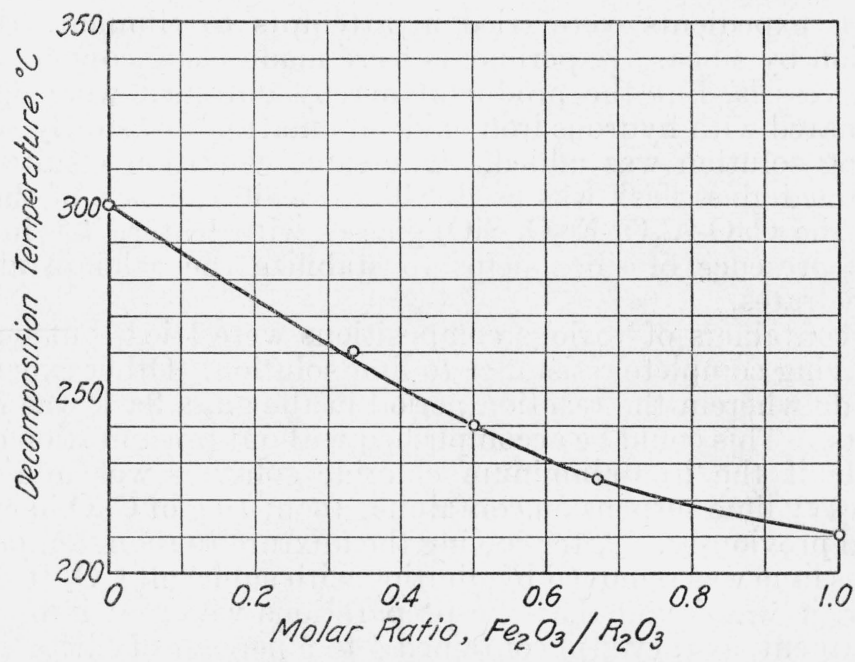

FIGURE 4.-Decomposition temperatures of hydrated calcium aluminoferrites containing silica.

appreciable quantities of hematite or gibbsite, as well as calcium hydroxide, appeared. The results are listed in table 3 . Figure 4 summarizes these data, the temperatures plotted being the average of the two limiting temperatures, except in the case of $3 \mathrm{CaO} \cdot \mathrm{Al}_{2} \mathrm{O}_{3} \cdot 6 \mathrm{H}_{2} \mathrm{O}$, where it was taken as $300^{\circ} \mathrm{C}$. 
TABLE 3.-Decomposition temperatures of hydrated calcium aluminoferrites

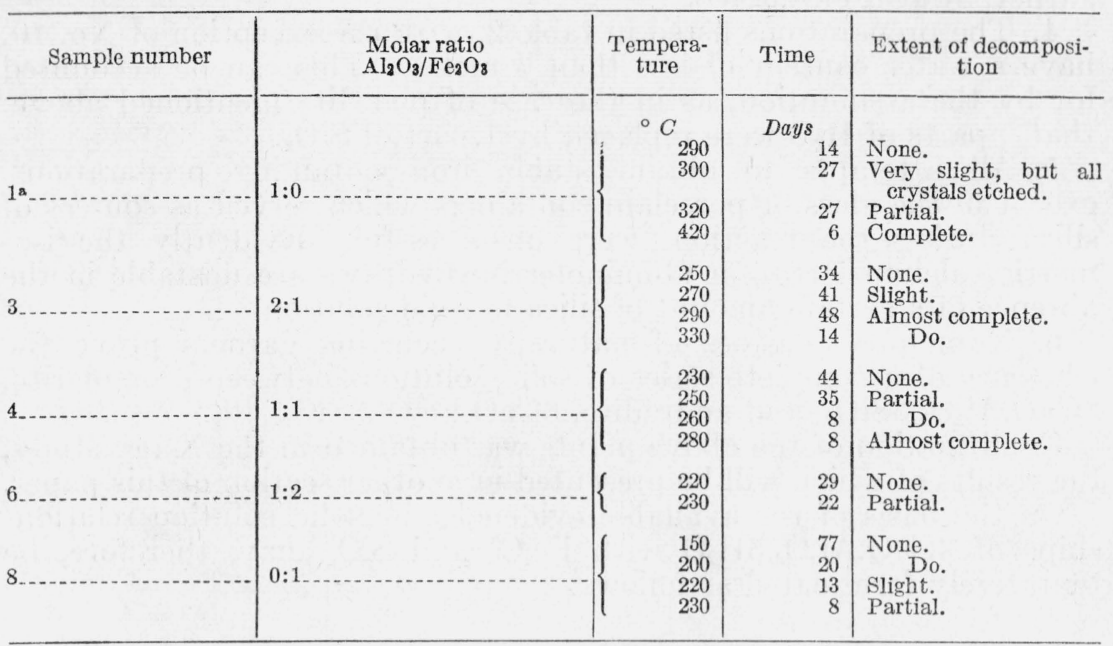

a Samples are numbered to correspond with the designations used in table 2 .

In spite of the long digestion periods below the decomposition temperatures, the crystal size of the hydrates was not greatly increased.

As will be shown later, the decomposition temperatures are influenced considerably by the presence of silica in the preparations. The fact that figure 4 is nearly a smooth curve probably is caused by the presence of roughly the same amounts of silica in the preparations, except in the $3 \mathrm{CaO} \cdot \mathrm{Al}_{2} \mathrm{O}_{3} \cdot 6 \mathrm{H}_{2} \mathrm{O}$ product.

\section{(d) DISCUSSION OF RESULTS}

The data in tables 1 and 2 indicate that $3 \mathrm{CaO} \cdot \mathrm{Al}_{2} \mathrm{O}_{3} \cdot 6 \mathrm{H}_{2} \mathrm{O}$ and $3 \mathrm{CaO} \cdot \mathrm{Fe}_{2} \mathrm{O}_{3} \cdot 6 \mathrm{H}_{2} \mathrm{O}$ form a complete series of solid solutions. However, it is evident from the following considerations that silica is also a factor in the solid solutions as follows:

1. The isometric product obtained from a glass containing 8.7 percent of $\mathrm{SiO}_{2}$ but no $\mathrm{Fe}_{2} \mathrm{O}_{3}$ (experiment 1, table 1), has a refractive index appreciably higher than that of ordinary $3 \mathrm{CaO} \cdot \mathrm{Al}_{2} \mathrm{O}_{3} \cdot 6 \mathrm{H}_{2} \mathrm{O}$.

2. The mineral plazolite, $3 \mathrm{CaO} \cdot \mathrm{Al}_{2} \mathrm{O}_{3} \cdot 2 \mathrm{SiO}_{2} \cdot 2 \mathrm{H}_{2} \mathrm{O},{ }^{2}$ [7] crystallizes in the isometric system with a refractive index of 1.675 [8] intermediate between $n=1.605$ for $3 \mathrm{CaO} \cdot \mathrm{Al}_{2} \mathrm{O}_{3} \cdot 6 \mathrm{H}_{2} \mathrm{O}$ and $n=1.735$ for grossularite garnet, $3 \mathrm{CaO} \cdot \mathrm{Al}_{2} \mathrm{O}_{3} \cdot 3 \mathrm{SiO}_{2}$. Winchell [9] has pointed out the similarity between plazolite and grossularite. The formula of plazolite can be accounted for by assuming that two molecules of $\mathrm{H}_{2} \mathrm{O}$ have replaced one molecule of $\mathrm{SiO}_{2}$ in grossularite, or that two molecules of $\mathrm{SiO}_{2}$ have replaced four molecules of $\mathrm{H}_{2} \mathrm{O}$ in $3 \mathrm{CaO} \cdot \mathrm{Al}_{2} \mathrm{O}_{3}$. $6 \mathrm{H}_{2} \mathrm{O}$.

3. Although no natural ferrite corresponding to plazolite is known, the presence of quantities of $\mathrm{SiO}_{2}$ up to 7.1 percent in the preparations of $3 \mathrm{CaO} \cdot \mathrm{Fe}_{2} \mathrm{O}_{3} \cdot 6 \mathrm{H}_{2} \mathrm{O}$ listed in table 2 points to the possibility of

2 The original formula, $3 \mathrm{CaO} . \mathrm{Al}_{2} \mathrm{O}_{3} \cdot 2 \mathrm{SiO}_{2} \cdot 2\left(\mathrm{CO}_{2}, \mathrm{H}_{2} \mathrm{O}\right)$, given for plazolite is incorrect, the carbonate content of the samples analyzed being due to the presence of small amounts of calcite. (Personal communication from W. F. Foshag). 
analogous solid solution between $3 \mathrm{CaO} \cdot \mathrm{Fe}_{2} \mathrm{O}_{3} \cdot 6 \mathrm{H}_{2} \mathrm{O}$ and andradite garnet, $3 \mathrm{CaO} \cdot \mathrm{Fe}_{2} \mathrm{O}_{3} \cdot 3 \mathrm{SiO}_{2}$.

4. The preparations listed in table 2, with the exception of No. 10, have a water content of less than 6 moles. This can be accounted for by the assumption, as in the case of plazolite mentioned above, that 2 parts of $\mathrm{H}_{2} \mathrm{O}$ were replaced by 1 part of $\mathrm{SiO}_{2}$.

5. All attempts to obtain stable iron-containing preparations, except in the glass or porcelain containers which served as sources of silica during the reaction, were unsuccessful. Evidently the isometric calcium ferrite or aluminoferrite hydrates are unstable in the absence of a certain amount of silica in solid solution.

6. Numerous analyses of naturally occurring garnets prove the existence of a complete series of solid solutions between grossularite, $3 \mathrm{CaO} \cdot \mathrm{Al}_{2} \mathrm{O}_{3} \cdot 3 \mathrm{SiO}_{2}$, and andradite, $3 \mathrm{CaO} \cdot \mathrm{Fe}_{2} \mathrm{O}_{3} \cdot 3 \mathrm{SiO}_{2}[10]$.

Confirmation of the above points was obtained in the X-ray study, the results of which will be presented in another section of this paper.

On the basis of the available evidence, the solid solution relationships of $3 \mathrm{CaO} \cdot \mathrm{Al}_{2} \mathrm{O}_{3} \cdot 6 \mathrm{H}_{2} \mathrm{O}$ with $\mathrm{Fe}_{2} \mathrm{O}_{3}$ and $\mathrm{SiO}_{2}$ may, therefore, be tentatively formulated as follows:

$$
\begin{gathered}
3 \mathrm{CaO} \cdot \mathrm{Al}_{2} \mathrm{O}_{3} \cdot 6 \mathrm{H}_{2} \mathrm{O}-3 \mathrm{CaO} \cdot \mathrm{Al}_{2} \mathrm{O}_{3} \cdot 3 \mathrm{SiO}_{2} \\
3 \mathrm{CaO} \cdot \mathrm{Fe}_{2} \mathrm{O}_{3} \cdot 6 \mathrm{H}_{2} \mathrm{O}-3 \mathrm{CaO} \cdot \mathrm{Fe}_{2} \mathrm{O}_{3} \cdot 3 \mathrm{SiO}_{2},
\end{gathered}
$$

each end member being capable of forming complete mixed crystals with the other three members. Each part of $\mathrm{Fe}_{2} \mathrm{O}_{3}$ displaces 1 part of $\mathrm{Al}_{2} \mathrm{O}_{3}$, while 1 part of $\mathrm{SiO}_{2}$ substitutes for 2 parts of $\mathrm{H}_{2} \mathrm{O}$.

\section{PREPARATION OF $3 \mathrm{CaO} \cdot \mathrm{Al}_{2} \mathrm{O}_{3} \cdot 6 \mathrm{H}_{2} \mathrm{O}-3 \mathrm{CaO} \cdot \mathrm{Fe}_{2} \mathrm{O}_{3} \cdot 6 \mathrm{H}_{2} \mathrm{O}-\mathrm{GROSSULAR}$ - ITE-ANDRADITE SOLID SOLUTIONS}

\section{(a) PROCEDURE}

In order to obtain homogeneous materials for hydrothermal treatment, glasses of the desired compositions were prepared from reagent quality calcium carbonate, alumina, ferric oxide, and purified silica gel ( 0.03 percent of nonvolatile residue on ignited basis). The mixtures were thoroughly ground and given a preliminary ignition at $1,200^{\circ} \mathrm{C}$. All melts were prepared in a platinum resistance furnace. Those having liquidus temperatures of 1,400 to $1,450^{\circ} \mathrm{C}$. were made in 5-g quantities in a furnace used for making experimental glasses; the remainder, in quantities of 0.5 to $1 \mathrm{~g}$, were wrapped in platinum foil and quenched from the higher temperatures. The melts were held above the liquidus temperatures for 15 minutes before quenching. Glasses of uniform index and free from birefringent material were thus obtained.

The oxide ratios of glasses prepared and the temperatures from which the liquids were quenched are given in table 4. As a check on the accuracy of the calculated compositions, glasses 13, 14, 17, 18 , and 19 were analyzed, with the results shown in table 4. 
TABLE 4.-Glasses prepared for study of solid solution relationships in the system $3 \mathrm{CaO} \cdot \mathrm{R}_{2} \mathrm{O}_{3} \cdot 3 \mathrm{SiO}_{2}-3 \mathrm{CaO} \cdot \mathrm{R}_{2} \mathrm{O}_{3} \cdot 6 \mathrm{H}_{2} \mathrm{O}$

\begin{tabular}{|c|c|c|c|c|c|c|c|c|c|c|c|c|c|c|}
\hline \multirow{3}{*}{$\begin{array}{l}\text { Sample } \\
\text { number }\end{array}$} & \multirow{2}{*}{\multicolumn{4}{|c|}{$\begin{array}{l}\text { Calculated oxide } \\
\text { ratios of glasses }\end{array}$}} & \multirow{3}{*}{$\begin{array}{c}\text { Tem- } \\
\text { per- } \\
\text { ature } \\
\text { of } \\
\text { quench- } \\
\text { ing }\end{array}$} & \multicolumn{9}{|c|}{ Compositions of glasses by analysis } \\
\hline & & & & & & \multicolumn{5}{|c|}{ Oxide analysis } & \multicolumn{4}{|c|}{ Oxide ratios a } \\
\hline & $0_{\infty}^{0}$ & 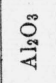 & 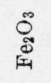 & $\stackrel{\circ}{\mathscr{0}}$ & & O & ○ొ & 怘 & 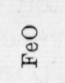 & $\stackrel{\odot}{\mathscr{C}}$ & 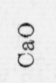 & 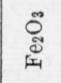 & $\frac{0}{4}$ & 踝 \\
\hline 11 & $\begin{array}{l}3 \\
3\end{array}$ & 1 & & 0.5 & ${ }^{\circ} \mathrm{C}$ & $\%$ & $\%$ & $\%$ & $\%$ & $\%$ & & & & \\
\hline & 3 & 1 & & 1 & 1,540 & & & & & & & & & \\
\hline $\begin{array}{l}13 . \\
14\end{array}$ & 3 & 1 & -.... & 2 & 1,540 & 43.15 & 25.25 & - & -1 & 31.62 & 3. 11 & 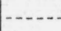 & 0.94 & 2.13 \\
\hline 14 & $\begin{array}{l}3 \\
3\end{array}$ & $\begin{array}{l}1 \\
0.5\end{array}$ & 0.5 & $\begin{array}{l}3 \\
1.5\end{array}$ & $\begin{array}{l}1,410 \\
1,540\end{array}$ & 37.27 & 22.75 & - & -. & 39.95 & 3.00 & $\cdots$ & 1.00 & 2.94 \\
\hline & 3 & .5 & .5 & 2 & 1,400 & & & & & & & & 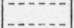 & - \\
\hline 17. & 3 & .5 & .5 & 3 & 1,450 & 35. 30 & 10.86 & 15. 68 & 0.99 & 37.25 & 2.93 & 0.49 & 0.51 & 2. 89 \\
\hline 18. & 3 & $-\ldots$ & 1 & 2 & 1,410 & 37.51 & & 35.02 & .80 & & 2. 97 & 1. 00 & -.... & 1.98 \\
\hline & 3 & $-\cdots$ & 1 & 3 & 1,400 & 33.11 & $-\ldots$ & 28.61 & 3.00 & 35.24 & 2. 96 & 1.00 & 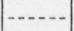 & 2.94 \\
\hline
\end{tabular}

a Oxideratios if $\mathrm{FeO}$ is calculated to $\mathrm{Fe}_{2} \mathrm{O}_{3}$.

The appearance of ferrous oxide in glasses 17, 18, and 19 introduces some uncertainty as to their suitability for hydrothermal treatment, but the amount of reduction is perhaps not sufficiently large to be significant except in the case of glass 19.

The preparation of a number of other glasses was attempted, but it was found that the melting points of the compositions $\left(3 \mathrm{CaO} \cdot \mathrm{Fe}_{2} \mathrm{O}_{3} \cdot \mathrm{SiO}_{2}\right.$, $6 \mathrm{CaO} .2 \mathrm{Fe}_{3} \mathrm{O}_{3} \cdot 3 \mathrm{SiO}_{2}$, and $6 \mathrm{CaO} \cdot \mathrm{Al}_{2} \mathrm{O}_{3} \cdot \mathrm{Fe}_{2} \mathrm{O}_{3} \cdot 2 \mathrm{SiO}_{2}$ ) were above the temperature range of the furnace.

As before, 0.5-g quantities of the finely powdered glasses were treated in the bombs with 5 to $10 \mathrm{ml}$ of water at various temperatures and for different lengths of time. The products were washed with alcohol and ether and dried in a desiccator over calcium chloride. Ignition-loss determinations, microscopical examinations, and X-ray patterns were then made of the products.

\section{(b) RESULTS OF ANALYTICAL AND MICROSCOPICAL DETERMINATIONS}

Table 5 summarizes the results of the hydrothermal treatment of the various glasses. As the table indicates, in the five cases in which more than one temperature was used, certain temperatures are more effective than others in bringing about crystallization. Above or below the optimum temperature, crystallization is either very slow or decomposition to more than one product occurs.

TABLE 5.-Products of hydrothermal treatment of glasses in the system $3 \mathrm{CaO} \cdot \mathrm{R}_{2} \mathrm{O}_{3} \cdot 3 \mathrm{SiO}_{2}-3 \mathrm{CaO} \cdot \mathrm{R}_{2} \mathrm{O}_{3} \cdot 6 \mathrm{H}_{2} \mathrm{O}$

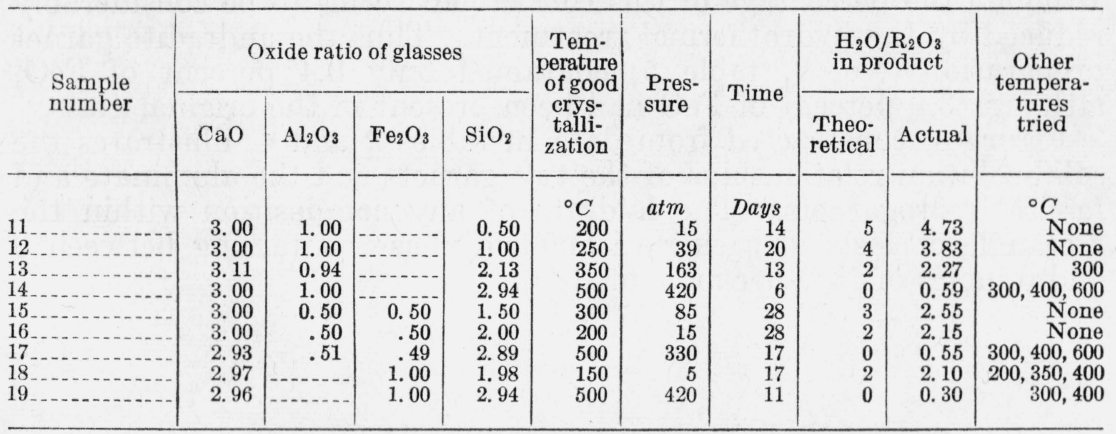


The preparations consisted, in all cases, of very small crystals of the isometric phase, the refractive index of which increased with increase in the $\mathrm{SiO}_{2}$ content of the treated glasses, both in the $\mathrm{Al}_{2} \mathrm{O}_{3}$ and $\mathrm{Fe}_{2} \mathrm{O}_{3}$ series. The refractive indices of the products from experiments 13 and 14 checked approximately those of plazolite and grossularite, respectively, but, in general, the refractive indices of the crystals could not be accurately determined because of their small size.

Departure of the water contents of the preparations from theoretical values is caused partially by the fact that in some cases a small percentage of unreacted glass remained after the hydrothermal treatment. Also, most of the products contained a few percent of poorly crystallized material, indicating that the action of the glass with water

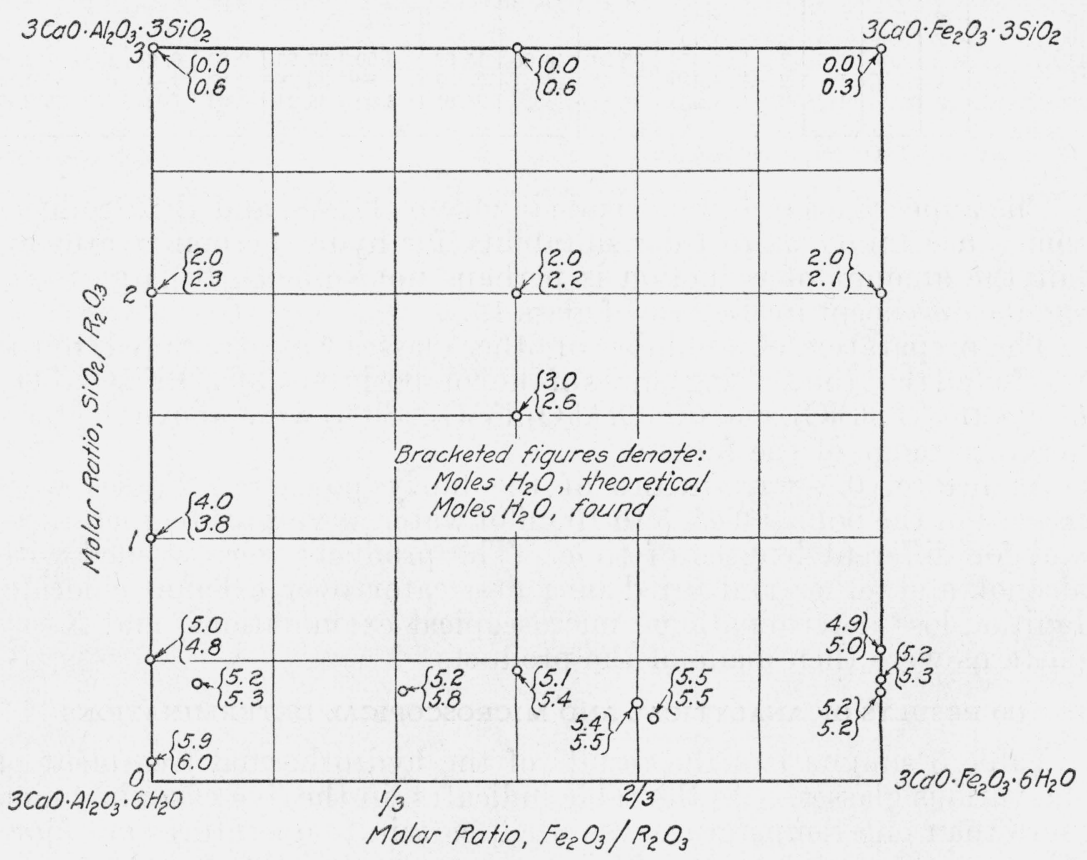

Figure 5.-Compositions prepared in the solid-solution series $3 \mathrm{CaO} \cdot \mathrm{R}_{2} \mathrm{O}_{3} \cdot 6 \mathrm{H}_{2} \mathrm{O}-3 \mathrm{CaO} \cdot \mathrm{R}_{2} \mathrm{O}_{3} \cdot 3 \mathrm{SiO}_{2}$.

was not completely uniform. In the case of the iron-containing glass, some of the difficulty is probably caused by the presence of $\mathrm{FeO}$, although the percentage of this constituent seems to be considerably reduced by the hydrothermal treatment. Thus the andradite garnet preparation (No. 9, table 5) contained only 0.4 percent of $\mathrm{FeO}$, although 3.0 percent of $\mathrm{FeO}$ had been present in the original glass.

Figure 5, constructed from data in tables 2 and 4 , illustrates the solid-solution relationships of the two garnets and the aluminate and ferrite hydrogarnets. The hydrate of any composition within the rectangle consists of a single isometric phase containing between 0 and 6 moles of $\mathrm{H}_{2} \mathrm{O}$ per mole of $\mathrm{R}_{2} \mathrm{O}_{3}$. 


\section{SUBSTITUTION OF OTHER OXIDES FOR CaO, $\mathrm{Al}_{2} \mathrm{O}_{3}$, AND $\mathrm{Fe}_{2} \mathrm{O}_{3}$ IN THE SOLID-SOLUTION SERIES}

In the hope of obtaining preparations better suited for crystallographic studies than $3 \mathrm{CaO} \cdot \mathrm{Al}_{2} \mathrm{O}_{3} \cdot 6 \mathrm{H}_{2} \mathrm{O}$ or $3 \mathrm{CaO} \cdot \mathrm{Fe}_{2} \mathrm{O}_{3} \cdot 6 \mathrm{H}_{2} \mathrm{O}$, synthesis of analogous compounds in which the $\mathrm{CaO}$ is replaced by $\mathrm{MgO}, \mathrm{MnO}, \mathrm{BaO}$, and $\mathrm{SrO}$, and the $\mathrm{Al}_{2} \mathrm{O}_{3}$ or $\mathrm{Fe}_{2} \mathrm{O}_{3}$ by $\mathrm{Cr}_{2} \mathrm{O}_{3}$ was attempted. As before, the method involved the very slow addition of solutions of the chlorides of aluminum and chromium to boiling solutions of calcium, barium, or strontium hydroxides. For preparation of the magnesium and manganese compounds, solutions of the chlorides of these two metals were added slowly to boiling solutions of sodium aluminate. In no case was a material obtained bearing any similarity to the isometric aluminate or ferrite hydrates. Brandenberger [6], however, has reported the existence of an isometric compound $3 \mathrm{SrO} . \mathrm{Al}_{2} \mathrm{O}_{3} \cdot 6 \mathrm{H}_{2} \mathrm{O}$, but he does not state how it was prepared.

A number of glasses having compositions corresponding to possible garnets were also made up and treated with water in the bombs at $500^{\circ} \mathrm{C}, 400$ atmospheres, for periods of 1 to 3 weeks. The products from $3 \mathrm{BaO} \cdot \mathrm{Al}_{2} \mathrm{O}_{3} \cdot 3 \mathrm{SiO}_{2}$ and $3 \mathrm{SrO} \cdot \mathrm{Al}_{2} \mathrm{O}_{3} \cdot 3 \mathrm{SiO}_{2}$ showed extensive decomposition to $\mathrm{Ba}(\mathrm{OH})_{2}$ and $\mathrm{Sr}(\mathrm{OH})_{2}$ and apparently contained none of the isometric phase. The glass $3 \mathrm{MgO} \cdot \mathrm{Al}_{2} \mathrm{O}_{3} \cdot 3 \mathrm{SiO}_{2}$ gave a finely divided, apparently heterogeneous product, none of the material having a refractive index as high as that of pyrope, the corresponding garnet $(n=1.725)$. A glass of equimolar proportions of $3 \mathrm{CaO} \cdot \mathrm{Al}_{2} \mathrm{O}_{3} \cdot 3 \mathrm{SiO}_{2}$ and $3 \mathrm{MgO} \cdot \mathrm{Al}_{2} \mathrm{O}_{3} \cdot 3 \mathrm{SiO}_{2}$ gave a product containing much birefringent material.

\section{PRODUCTS OF REACTION OF WATER WITH TETRACALCIUM ALUMINOFERRITE}

The reaction of tetracalcium aluminoferrite with a large excess of water appears to be somewhat different from that which occurs when the ferrite is mixed with only enough water to form a paste.

In the experiments with a large excess of water, $100 \mathrm{~g}$ of $4 \mathrm{CaO} \cdot \mathrm{Al}_{2} \mathrm{O}_{3} \cdot \mathrm{Fe}_{2} \mathrm{O}_{3}$ was shaken with 2 liters of $\mathrm{CO}_{2}$-free water for various lengths of time, the solutions filtered, and analyses for dissolved lime and alumina made on 200-ml aliquots of the filtrates. The concentrations (expressed as $\mathrm{g}$ of $\mathrm{CaO}$ and $\mathrm{Al}_{2} \mathrm{O}_{3}$ per liter) in the resulting solutions, which contained no $\mathrm{Fe}_{2} \mathrm{O}_{3}$, are shown in figure 6 .

The concentration of the alumina in solution increased rapidly with the time of shaking, and reached a maximum in 30 minutes, after which it decreased gradually. A similar change occurred with the lime in solution but differed from that of the alumina in that the concentrations were higher. This is in contrast to the mechanism of the reaction of water on the calcium aluminates and calcium aluminate cements, where the concentration of the alumina in solution in the early stages greatly exceeds that of the lime and becomes in some instances over $2 \mathrm{~g}$ of $\mathrm{Al}_{2} \mathrm{O}_{3}$ per liter [4].

All of these solutions were metastable and gave "silky" precipitates on standing. After 3 months, the precipitates were examined microscopically. They consisted of the hexagonal forms of hydrated calcium aluminate with, in most cases, smaller proportions of isometric $3 \mathrm{CaO} \cdot \mathrm{Al}_{2} \mathrm{O}_{3} \cdot 6 \mathrm{H}_{2} \mathrm{O}$ of normal index, $n=1.605$. 
One of the mixtures of $4 \mathrm{CaO} \cdot \mathrm{Al}_{2} \mathrm{O}_{3} \cdot \mathrm{Fe}_{2} \mathrm{O}_{3}$ and water was allowed to stand for 10 years at room temperature, with occasional shaking. Analysis of this solution showed but a trace of alumina. The lime in solution was $1.087 \mathrm{~g}$ of $\mathrm{CaO}$ per liter, slightly less than that of a saturated lime solution. This increase in concentration of lime was accompanied by the disappearance of the hexagonal forms of hydrated calcium aluminate and of the anhydrous phase. The solid residue was a mixture of isometric crystals and finely divided reddish material. The bulk of the isometric crystals had the normal refractive index of $3 \mathrm{CaO} \cdot \mathrm{Al}_{2} \mathrm{O}_{3} \cdot 6 \mathrm{H}_{2} \mathrm{O}$. A relatively small proportion possessed a higher

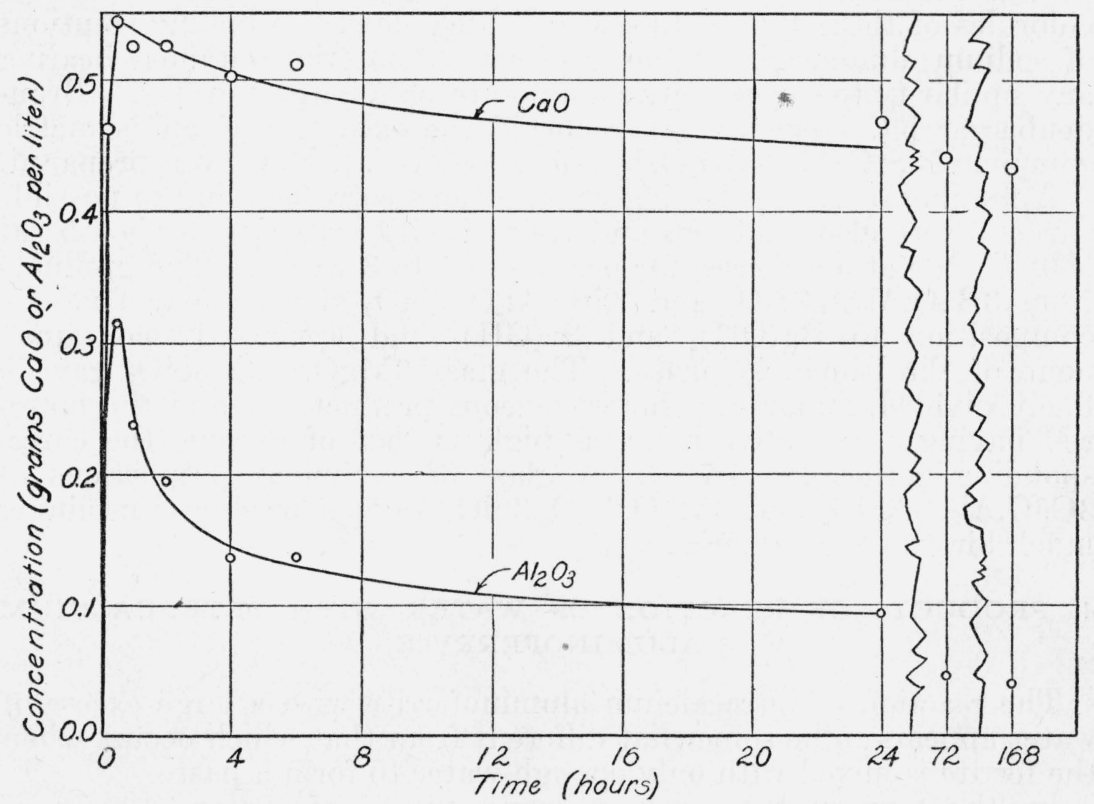

FIGURE 6.-Solutions obtained by shaking tetracalcium aluminoferrite with water.

index of refraction, with a maximum value of about 1.637. An X-ray determination of the unit-cube size of the product checked the value of pure $3 \mathrm{CaO} \cdot \mathrm{Al}_{2} \mathrm{O}_{3} \cdot 6 \mathrm{H}_{2} \mathrm{O}$. The quantity of the material of higher refractive index was too small to have any apparent effect on the pattern.

The reaction of tetracalcium aluminoferrite with a large excess of water appears, therefore, to involve the formation of supersaturated solutions containing $\mathrm{CaO}$ and $\mathrm{Al}_{2} \mathrm{O}_{3}$ but no $\mathrm{Fe}_{2} \mathrm{O}_{3}$, the precipitation of the hexagonal forms of hydrated calcium aluminate, and the gradual transformation of these forms into the isometric hydrated aluminate. Since most of the isometric crystals have the index of refraction and the unit-cube size of $3 \mathrm{CaO} \cdot \mathrm{Al}_{2} \mathrm{O}_{3} \cdot 6 \mathrm{H}_{2} \mathrm{O}$, practically all of the $\mathrm{Fe}_{2} \mathrm{O}_{3}$ from the original $4 \mathrm{CaO} \cdot \mathrm{Al}_{2} \mathrm{O}_{3} \cdot \mathrm{Fe}_{2} \mathrm{O}_{3}$ must be contained in the accompanying finely divided reddish material.

In order to investigate the reaction when only a limited amount of water is present, a paste of $10 \mathrm{~g}$ of tetracalcium aluminoferrite and $5 \mathrm{~g}$ of water was stored in a sealed glass vial for 6 days. Microscopical examination of the mixture showed the presence of about 20 percent 
of unhydrated $4 \mathrm{CaO} \cdot \mathrm{Al}_{2} \mathrm{O}_{3} \cdot \mathrm{Fe}_{2} \mathrm{O}_{3}$ with the alteration products consisting of a mixture of reddish amorphous material and of isometric crystals with index of 1.63 to 1.64 .

Because of the increased refractive index, it appears probable that this material contained some $\mathrm{Fe}_{2} \mathrm{O}_{3}$ in solid solution. As is explained in detail later in this paper, an increased unit cell results from the replacement, in whole or in part, of the $\mathrm{Al}_{2} \mathrm{O}_{3}$ by $\mathrm{Fe}_{2} \mathrm{O}_{3}$ in this structure, and the increase is in direct proportion to the amount of $\mathrm{Al}_{2} \mathrm{O}_{3} \mathrm{re}$ placed. An X-ray powder pattern was made of this material, and a measurement of the unit cell indicated an increased size, this in turn confirming the result of the determination of the refractive index.

The pure $3 \mathrm{CaO} \cdot \mathrm{Al}_{2} \mathrm{O}_{3} \cdot 6 \mathrm{H}_{2} \mathrm{O}$ has a unit-cube size of $12.56 \mathrm{~A}$, while $3 \mathrm{CaO} . \mathrm{Fe}_{2} \mathrm{O}_{3} \cdot 6 \mathrm{H}_{2} \mathrm{O}$ has a cube of $12.74 \mathrm{~A}$. The hydrate prepared from $4 \mathrm{CaO} \cdot \mathrm{Al}_{2} \mathrm{O}_{3} \cdot \mathrm{Fe}_{2} \mathrm{O}_{3}$ had a cell size of $12.60 \mathrm{~A}$, thus $0.04 \mathrm{~A}$ larger than that of the pure calcium aluminate hydrate.

Lerch and Bogue [11] likewise found that the isometric phase from $4 \mathrm{CaO} \cdot \mathrm{Al}_{2} \mathrm{O}_{3} \cdot \mathrm{Fe}_{2} \mathrm{O}_{3}$ pastes had a refractive index of 1.640 . Their failure to find any displacement in its X-ray pattern is probably due to the fact that the shift is very small and not easily detected by the camera which they used.

A sample of dry $4 \mathrm{CaO} \cdot \mathrm{Al}_{2} \mathrm{O}_{3} \cdot \mathrm{Fe}_{2} \mathrm{O}_{3}$ steamed in an autoclave at $150^{\circ} \mathrm{C}$ for 6 days still contained a considerable quantity of the anhydrous ferrite. The isometric product, as before, had a refractive index of 1.63 to 1.64 and a unit-cube size, calculated from the X-ray pattern, of $12.60 \mathrm{~A}$. The index of refraction of the isometric phase is somewhat higher than the value reported by Mather and Thorvaldson [12] for the isometric grains obtained by steaming: $4 \mathrm{CaO} \cdot \mathrm{Al}_{2} \mathrm{O}_{3} \cdot \mathrm{Fe}_{2} \mathrm{O}_{3}$ at $150^{\circ} \mathrm{C}$ and other temperatures.

In another experiment, $2 \mathrm{~g}$ of $4 \mathrm{CaO} \cdot \mathrm{Al}_{2} \mathrm{O}_{3} \cdot \mathrm{Fe}_{2} \mathrm{O}_{3}$ was treated with 5 $\mathrm{ml}$ of water at $225^{\circ} \mathrm{C}$ for 3 weeks. No unhydrated $4 \mathrm{CaO} \cdot \mathrm{Al}_{2} \mathrm{O}_{3} \cdot \mathrm{Fe}_{2} \mathrm{O}_{3}$ remained in the product. The index of refraction of the isometric phase showed approximately the same variation as before, and a determination of the unit-cube size gave a value of $12.62 \mathrm{~A}$.

\section{BEARING OF RESULTS ON PRODUCTS OF HYDRATION OF PORTLAND CEMENT}

The foregoing results suggest that the hydration products of the tetracalcium aluminoferrite and glass of portland cement belong to the solid-solution series described in this paper. Whether or not similar hydrates are formed during the reaction with water of the silicates and aluminate compounds which may be in portland cement has not been proved. However, some recent work reported by Büssem [13] indicates that this may be the case.

According to Büssem, a product having the composition $3 \mathrm{CaO}$. $\mathrm{Al}_{2} \mathrm{O}_{3} \cdot 2 \mathrm{SiO}_{2} \cdot x \mathrm{H}_{2} \mathrm{O}$ (cf. plazolite, $3 \mathrm{CaO} \cdot \mathrm{Al}_{2} \mathrm{O}_{3} \cdot 2 \mathrm{SiO}_{2} \cdot 2 \mathrm{H}_{2} \mathrm{O}$ ) is obtained in the reaction of limewater on dehydrated kaolin and also when $3 \mathrm{CaO} \cdot \mathrm{SiO}_{2}$ and $3 \mathrm{CaO} \cdot \mathrm{Al}_{2} \mathrm{O}_{3}$ are precipitated in water. On account of the finely divided state of his product, it was impossible to ascertain microscopically whether it consisted of one, or more than one, phase. On heating the material to $1,200^{\circ} \mathrm{C}$, it was converted to a mixture of gehlenite $\left(2 \mathrm{CaO} \cdot \mathrm{Al}_{2} \mathrm{O}_{3} \cdot \mathrm{SiO}_{2}\right)$ and pseudowollastonite $\left(\mathrm{CaO} . \mathrm{SiO}_{2}\right)$. This was advanced by Büssem as proof that the original hydrate was a mixture of hydrated gehlenite $\left(2 \mathrm{CaO} \cdot \mathrm{Al}_{2} \mathrm{O}_{3} \cdot \mathrm{SiO}_{2} \cdot x \mathrm{H}_{2} \mathrm{O}\right)$ 
and hydrated tricalcium disilicate. However, it would seem at least equally permissible to assume that the original material consisted of a single phase, possibly related to the mineral plazolite, which decomposed according to the equation: $3 \mathrm{CaO} \cdot \mathrm{Al}_{2} \mathrm{O}_{3} \cdot 2 \mathrm{SiO}_{2} \cdot x \mathrm{H}_{2} \mathrm{O}=$ $2 \mathrm{CaO} . \mathrm{Al}_{2} \mathrm{O}_{3} \cdot \mathrm{SiO}_{2}+\mathrm{CaO} \cdot \mathrm{SiO}_{2}+x \mathrm{H}_{2} \mathrm{O}$.

The possible formation of hydrated calcium aluminosilicate during the reaction of water with portland cement-burnt clay and similar puzzolan mixtures may explain the high resistance to sulfate action of mortars made from such materials. As Lea [14] has pointed out, this has long been a perplexing question, since it might have been supposed that any increase in the alumina content of the mortar would tend to promote formation of additional calcium sulfoaluminate and bring about increased deterioration.

\section{SUMMARY OF HYDROTHERMAL STUDY}

It has been shown that the isometric compounds: $3 \mathrm{CaO} \cdot \mathrm{Al}_{2} \mathrm{O}_{3}$. $6 \mathrm{H}_{2} \mathrm{O}, 3 \mathrm{CaO} \cdot \mathrm{Fe}_{2} \mathrm{O}_{3} \cdot 6 \mathrm{H}_{2} \mathrm{O}, 3 \mathrm{CaO} \cdot \mathrm{Al}_{2} \mathrm{O}_{3} \cdot 3 \mathrm{SiO}_{2}$ (grossularite), and $3 \mathrm{CaO}$. $\mathrm{Fe}_{2} \mathrm{O}_{3} .3 \mathrm{SiO}_{2}$ (andradite), form complete solid solutions with each other. Plazolite $\left(3 \mathrm{CaO} \cdot \mathrm{Al}_{2} \mathrm{O}_{3} \cdot 2 \mathrm{SiO}_{2} \cdot 2 \mathrm{H}_{2} \mathrm{O}\right)$ belongs to this series. Various members of the group were synthesized by hydrothermal treatment of glasses of the proper compositions and by the reaction of iron and aluminum chlorides with boiling calcium hydroxide solution.

The principal product of hydration at elevated temperatures and pressures of various glasses representative of compositions of the liquid phase of cement clinker at $1,400^{\circ} \mathrm{C}$, appears to belong to this solid-solution series, as does also the principal hydration product of tetracalcium aluminoferrite. Recent investigations reported by Büssem indicate that hydrates of the calcium aluminosilicate series may be formed during the reaction of mixtures of tricalcium silicate and tricalcium aluminate with water.

Attempts to substitute $\mathrm{MgO}, \mathrm{MnO}, \mathrm{BaO}$, and $\mathrm{SrO}$ for $\mathrm{CaO}$ in the series, and to replace $\mathrm{Al}_{2} \mathrm{O}_{3}$ or $\mathrm{Fe}_{2} \mathrm{O}_{3}$ by $\mathrm{Cr}_{2} \mathrm{O}_{3}$, were unsuccessful.

\section{X-RAY STRUCTURE STUDIES}

\section{By Howard F. McMurdie}

\section{INTRODUCTION AND METHODS}

It was considered desirable to confirm the solid solutions encountered in the foregoing work by a study of the changes in atomic structure involved. In most cases, end members of complete solid-solution series have atomic arrangements in the same space group, or at least in closely related ones, and the change in X-ray pattern from that of one end member to another will be gradual. Thus the positions and relative intensities of the lines will change continuously as the composition varies and not in steps.

Also, since the synthesis of garnet has never before been confirmed by X-ray patterns, it was thought desirable to do so in this investigation.

Because the crystalline material produced by the hydrothermal methods used here was mostly very fine grained, powder patterns were used exclusively in this work. 
The samples were mounted on fine glass rods in the center of cylindrical cameras having radii of about $5.7 \mathrm{~cm}$, and were rotated during exposure. $\mathrm{Cu} K \alpha$ radiation was used. The radii of the cameras were checked by $\mathrm{NaCl}$. The positions of the lines were measured to $0.01 \mathrm{~cm}$, and the intensities were estimated.

\section{STRUCTURE OF $3 \mathrm{CaO} \cdot \mathrm{Al}_{2} \mathrm{O}_{3} \cdot 6 \mathrm{H}_{2} \mathrm{O}$}

The indexed interplanar spacings and relative intensities for the lines of $3 \mathrm{CaO} \cdot \mathrm{Al}_{2} \mathrm{O}_{3} \cdot 6 \mathrm{H}_{2} \mathrm{O}$ are given in table 6 . This pattern indicates a cubic structure with the side of the unit cube equal to $12.56 \mathrm{~A}$ \pm 0.02 .

TABLE 6.-Interplanar spacing and estimated and calculated relative intensities of $3 \mathrm{CaO} . \mathrm{Al}_{2} \mathrm{O}_{3} \cdot 6 \mathrm{H}_{2} \mathrm{O}$

$$
[a=12.56 \mathrm{~A}]
$$

[ $V S=$ very strong; $V W=$ very weak; $M=$ medium; $S=$ strong; $W=$ weak]

\begin{tabular}{|c|c|c|c|}
\hline 1 & 2 & 3 & 4 \\
\hline$h k l$ & $d$ & $\begin{array}{l}\text { Estimated } \\
\text { relative } \\
\text { intensities }\end{array}$ & $\begin{array}{l}\text { Calculated } \\
\text { relative } \\
\text { intensities }\end{array}$ \\
\hline $\begin{array}{c}211 \\
220 \\
321 \\
400 \\
420 \\
332 \\
422 \\
431 \\
521 \\
440 \\
611-532 \\
620 \\
541 \\
631 \\
444 \\
543 \\
640 \\
633-552-721 \\
642 \\
651-732 \\
800 \\
840\end{array}$ & $\begin{array}{l}5.16 \\
4.47 \\
3.37 \\
3.15 \\
2.81 \\
(\mathrm{a}) \\
2.56 \\
2.46 \\
2.30 \\
2.220 \\
2.039 \\
1.992 \\
(\mathrm{a}) \\
(\mathrm{a}) \\
1.812 \\
(\mathrm{a}) \\
1.741 \\
1.711 \\
1.680 \\
1.600 \\
1.571 \\
1.405\end{array}$ & $\begin{array}{c}V S \\
M \\
M \\
M \\
M \\
V W \\
W \\
V S \\
V W \\
S \\
V W \\
V W \\
W \\
W \\
M \\
V W \\
W \\
W\end{array}$ & $\begin{array}{r}1,430 \\
510 \\
600 \\
300 \\
930 \\
39 \\
160 \\
306 \\
1,470 \\
72 \\
1,145 \\
136 \\
48 \\
23 \\
166 \\
15 \\
270 \\
340 \\
745 \\
186 \\
230 \\
-. .--\end{array}$ \\
\hline
\end{tabular}

a Not observed on film.

As mentioned earlier in the paper, this compound crystallizes in various forms, such as cubes, octahedrons, dodecahedrons, and icositetrahedrons. The fact that all these are holohedral forms indicates strongly that this compound is in the cubic holohedric class.

From a study of the plane indices $(h k l)$ in column 1 , it is evident that in all cases $h+k+l=2 n$. This indicates a body-centered lattice. There are only two space groups in the cubic holohedral class based on a body-centered lattice: $\mathrm{O}_{h}^{9}$ and $\mathrm{O}_{h}^{10}$ Space group $\mathrm{O}_{h}^{10}$ also requires the absence of all first-order reflections of $h k \mathrm{O}$ (such as 130,350 , etc.). No such reflections are found in these patterns, and therefore it is almost certain that $\mathrm{O}_{h}^{10}$ is the proper space group. 
Grossularite was found to be in this space group by Menzer [15]. He also found eight molecules to a unit cube with $a=11.84 \mathrm{~A}$, and atomic positions as follows:

$$
\begin{aligned}
& 16 \mathrm{Al} \text { in } 16 a\left(\begin{array}{lll}
0 & 0 & 0
\end{array}\right)[16] \\
& 24 \mathrm{Ca} \text { in } 24 c(1 / 41 / 20) \\
& 24 \mathrm{Si} \text { in } 24 d(1 / 43 / 80) \\
& 96 \mathrm{O} \text { in } 96 h(x, y, z)
\end{aligned}
$$

with $x=0.04, y=0.055$, and $z=0.65$.

This structure consists of tetrahedrons with $\mathrm{Si}$ atoms at the centers and $\mathrm{O}$ atoms at the corners, the tetrahedrons being connected through $\mathrm{Ca}$ and $\mathrm{Al}$ atoms. In grossularite, since there are four $\mathrm{O}$ atoms for each $\mathrm{Si}$ atom, no $\mathrm{O}$ atoms are shared by two tetrahedrons, each $\mathrm{O}$ atom being bonded to one $\mathrm{Si}$ and to $\mathrm{Ca}$ or $\mathrm{Al}$ atoms. The interatomic distances are typical ones for silicate structures. The distance between $\mathrm{O}$ atoms in a single tetrahedron equals about $2.8 \mathrm{~A}$. The distances between $\mathrm{Al}$ atoms and $\mathrm{O}$ atoms are $1.9 \mathrm{~A}$, while the $\mathrm{Ca}-\mathrm{O}$ distances are $2.4 \mathrm{~A}$.

It may be assumed that the structure of $3 \mathrm{CaO} \cdot \mathrm{Al}_{2} \mathrm{O}_{3} \cdot 6 \mathrm{H}_{2} \mathrm{O}$ will be similar. The $16 \mathrm{Al}$ and the $24 \mathrm{Ca}$ atoms can be placed in the same special positions as in garnet. The spaces taken by $\mathrm{Si}$ will be vacant, and the $\mathrm{O}$ and $\mathrm{H}$ atoms will be in the two sets of the general $x y z$ positions with different parameters. Because of the extremely low reflectivity of $\mathrm{H}$ atoms, it is impossible to place them with any degree of accuracy in a structure having as many heavier atoms as this compound contains.

If the same $x y z$ values are assumed for this compound as in grossularite, the effect upon interatomic distances is a general increase of every distance proportioned to the increase of the unit cell from $11.84 \mathrm{~A}$ for the garnet to $12.56 \mathrm{~A}$. This is obviously improbable. The Ca-O and Al-O distances would be expected to remain almost unchanged, and the increased cube size would result not from a general increase but from an increase in $\mathrm{O}-\mathrm{O}$ distance resulting from the removal of the $\mathrm{Si}$ atoms at the centers of the tetrahedrons.

Using $x=0.025, y=0.05$, and $z=0.64$, the $\mathrm{O}-\mathrm{O}$ distances are increased from the $2.8 \mathrm{~A}$ in garnet to an average of $3.2 \mathrm{~A}$ in $3 \mathrm{CaO}_{2} \mathrm{Al}_{2} \mathrm{O}_{3} \cdot 6 \mathrm{H}_{2} \mathrm{O}$. The Al-O and $\mathrm{Ca}-\mathrm{O}$ distances remain the same as in grossularite garnet.

These atomic positions were confirmed by calculating the relative intensities resulting from this arrangement and by comparing them with those estimated from the film.

The formula

$$
I_{h k l}=J F^{2}\left(\frac{1+\cos ^{2} 2 \theta}{\sin ^{2} \theta \cos \theta}\right)
$$

where

$I=$ relative intensity

$J=$ number of cooperating planes in the form

$\mathrm{F}=$ structure factor

$\theta=$ glancing angle

was used, with James and Brindley's scattering values [16]. 
The calculated values of $I$ for all planes possible in $\mathrm{O}_{h}^{10}$ with $h^{2}+k^{2}+$ $l^{2}<64$ are given in column 4 of table 6 . The values show good agreement with the estimated intensities.

\section{THE SERIES $3 \mathrm{CaO} \cdot(\mathrm{Al}, \mathrm{Fe})_{2} \mathrm{O}_{3} \cdot 3 \mathrm{SiO}_{2}-3 \mathrm{CaO} \cdot(\mathrm{Al}, \mathrm{Fe})_{2} \mathrm{O}_{3} \cdot 6 \mathrm{H}_{2} \mathrm{O}$.}

As reported in an earlier part of this paper, crystalline products, which are between $3 \mathrm{CaO} \cdot \mathrm{Al}_{2} \mathrm{O}_{3} \cdot 6 \mathrm{H}_{2} \mathrm{O}$ and grossularite $\left(3 \mathrm{CaO} \cdot \mathrm{Al}_{2} \mathrm{O}_{3} \cdot 3 \mathrm{SiO}_{2}\right)$ in composition, have been prepared hydrothermally. Similar compounds, in which part or all of the alumina has been replaced by $\mathrm{Fe}_{2} \mathrm{O}_{3}$, have also been prepared. All of these compounds are isotropic and have refractive indices intermediate between those of the end numbers.

To confirm the existence of the solid-solution series by X-ray patterns, it is necessary to find that the positions and relative intensities of the lines of the patterns are intermediate between those of the end members involved. First, patterns of natural garnets of high purity were made. The samples of grossularite $\left(3 \mathrm{CaO} \cdot \mathrm{Al}_{2} \mathrm{O}_{3} \cdot 3 \mathrm{SiO}_{2}\right)$ and andradite $\left(3 \mathrm{CaO} \cdot \mathrm{Fe}_{2} \mathrm{O}_{3} \cdot 3 \mathrm{SiO}_{2}\right)$ were obtained from the National $\mathrm{Mu}$ seum, through the courtesy of W. F. Foshag. Tables 7 and 8 give the indexed powder patterns of these compounds. The unit-cube size found for grossularite was $11.84 \mathrm{~A}$ and that of andradite equaled 12.02 A. These agree with the published values for these cell sizes [17].

It is seen that the increase in unit-cell size due to the complete replacement in grossularite of $3 \mathrm{SiO}_{2}$ by $6 \mathrm{H}_{2} \mathrm{O}$ equals $12.56 \mathrm{~A}-11.84 \mathrm{~A}$, or $0.72 \mathrm{~A}$. Any compound of intermediate composition must have a unit cube between these limits if it is a member of this isomorphous series. Table 9 gives unit-cell sizes for various prepared compositions. Those containing no $\mathrm{Fe}_{2} \mathrm{O}_{3}$ (i. e., 1, 12, 13, 14), and having compositions intermediate between those of $3 \mathrm{CaO} \cdot \mathrm{Al}_{2} \mathrm{O}_{3} \cdot 3 \mathrm{SiO}_{2}$ and of $3 \mathrm{CaO} \cdot \mathrm{Al}_{2} \mathrm{O}_{3} \cdot 6 \mathrm{H}_{2} \mathrm{O}$, in all cases show intermediate unit-cube sizes between those of the above compounds as end members of this series.

TABLE 7.-Interplanar spacings and estimated relative intensities of grossularite

$[a=11.84 \pm 0.02 \mathrm{~A}]$

[ $V S=$ very strong; $V W=$ very weak; $M=$ medium; $S=$ strong; $W=$ weak ]

\begin{tabular}{|c|c|c|}
\hline$h k l$ & $d$ & $\begin{array}{c}\text { Estimated } \\
\text { intensity }\end{array}$ \\
220 & 4.14 & \\
400 & 2.98 & $V W$ \\
420 & 2.65 & $S$ \\
332 & 2.51 & $W$ \\
422 & 2.42 & $W$ \\
431 & 2.33 & $M$ \\
521 & 2.165 & $M$ \\
440 & 2.093 & $M W$ \\
$611-532$ & 1.928 & $S$ \\
620 & 1.871 & $V W$ \\
444 & 1.711 & $M$ \\
640 & 1.645 & $S$ \\
642 & 1.538 & $V S$ \\
800 & 1.486 & $M$ \\
752 & 1.337 & $M$ \\
833 & 1.296 & $S$ \\
664 & 1.264 & $W$ \\
$851-784$ & 1.252 & $V W$ \\
& & $V$ \\
\hline
\end{tabular}


TABLE 8.-Interplanar spacings of and estimated relative intensities of andradite

\section{$[a=12.02 \pm 0.02 \mathrm{~A}]$}

[ $V S=$ very strong; $V W=$ very weak; $M=$ medium; $S=$ strong; $W=$ weak ]

\begin{tabular}{|c|c|c|}
\hline$h k l$ & $d$ & $\begin{array}{c}\text { Estimated } \\
\text { intensity }\end{array}$ \\
\cline { 1 - 1 } 220 & 4.24 & \\
400 & 3.01 & $W$ \\
420 & 2.69 & $S$ \\
332 & 2.56 & $V S$ \\
422 & 2.454 & $V W$ \\
431 & 2.349 & $S$ \\
521 & 2.195 & $W$ \\
$611-532$ & 1.951 & $W$ \\
620 & 1.893 & $M$ \\
444 & 1.735 & $W$ \\
640 & 1.665 & $M$ \\
642 & 1.606 & $V S$ \\
800 & 1.506 & $W$ \\
840 & 1.348 & $M$ \\
842 & 1.309 & $M$ \\
$932-763$ & 1.249 & $M$ \\
$941-853$ & 1.214 & $V W$ \\
$10.40-864$ & 1.113 & $M$ \\
& & $M$ \\
\hline
\end{tabular}

TABLE 9.-Unit-cell size of preparations in the garnet-hydrogarnet series

\begin{tabular}{|c|c|c|c|c|c|c|}
\hline \multirow{2}{*}{ Sample number } & \multicolumn{5}{|c|}{ Molar ratio } & \multirow{2}{*}{$a \pm 0.02 \mathrm{~A}$} \\
\hline & $\mathrm{CaO}$ & $\mathrm{Al}_{2} \mathrm{O}_{3}$ & $\mathrm{Fe}_{2} \mathrm{O}_{3}$ & $\mathrm{SiO}_{2}$ & $\mathrm{H}_{2} \mathrm{O}$ & \\
\hline $\begin{array}{l}1 \\
2 \\
3 \\
4 \\
5\end{array}$ & $\begin{array}{l}\text { 3. } 06 \\
\text { 3. } 07 \\
\text { 3. } 18 \\
\text { 3. } 15 \\
2.88\end{array}$ & $\begin{array}{r}1.00 \\
0.94 \\
.66 \\
.50 \\
.31\end{array}$ & $\begin{array}{r}0.06 \\
.34 \\
.50 \\
.69\end{array}$ & $\begin{array}{l}0.07 \\
.41 \\
.38 \\
.46 \\
.23\end{array}$ & $\begin{array}{l}5.97 \\
5.31 \\
5.84 \\
5.42 \\
5.52\end{array}$ & $\begin{array}{l}12.56 \\
12.40 \\
12.55 \\
12.64 \\
12.66\end{array}$ \\
\hline $\begin{array}{l}7 \\
8 \\
9 \\
10 \\
12\end{array}$ & $\begin{array}{l}\text { 3. } 07 \\
\text { 3. } 12 \\
\text { 3. } 08 \\
\text { 3. } 54 \\
\text { 3. } 00\end{array}$ & 1.00 & $\begin{array}{l}1.00 \\
1.00 \\
1.00 \\
1.00\end{array}$ & $\begin{array}{r}.38 \\
.42 \\
.54 \\
.52 \\
1.00\end{array}$ & $\begin{array}{l}5.24 \\
5.34 \\
4.97 \\
6.01 \\
3.83\end{array}$ & $\begin{array}{l}12.63 \\
12.64 \\
12.66 \\
12.74 \\
12.25\end{array}$ \\
\hline 13 15 15 & $\begin{array}{l}\text { 3. } 11 \\
\text { 3. } 00 \\
\text { 3. } 00 \\
\text { 3. } 00 \\
\text { 2. } 93\end{array}$ & $\begin{array}{r}0.94 \\
1.00 \\
0.50 \\
.50 \\
.51\end{array}$ & $\begin{array}{l}.50 \\
.50 \\
.49\end{array}$ & $\begin{array}{l}2.13 \\
2.94 \\
1.50 \\
2.00 \\
2.89\end{array}$ & $\begin{array}{l}2.27 \\
0.59 \\
2.55 \\
2.15 \\
0.55\end{array}$ & $\begin{array}{l}12.04 \\
11.91 \\
12.25 \\
12.18 \\
11.96\end{array}$ \\
\hline 18 & $\begin{array}{l}2.97 \\
2.96\end{array}$ & $\cdots$ & $\begin{array}{l}1.00 \\
1.00\end{array}$ & $\begin{array}{l}1.98 \\
2.94\end{array}$ & $\begin{array}{l}2.10 \\
0.30\end{array}$ & $\begin{array}{l}12.35 \\
12.06\end{array}$ \\
\hline
\end{tabular}

In the case of number 14, with very little $\mathrm{H}_{2} \mathrm{O}$ present, the pattern approaches closely that of natural garnet in the relative intensities as well as in cube size.

The change in cell size resulting from the replacement of $\mathrm{Al}_{2} \mathrm{O}_{3}$ by $\mathrm{Fe}_{2} \mathrm{O}_{3}$ can be found by comparing the cell sizes of the two natural garnets. The change equals $12.02 \mathrm{~A}-11.84 \mathrm{~A}$, or $0.18 \mathrm{~A}$.

Because of the similarity of structure, the same difference in cell size exists between $3 \mathrm{CaO} \cdot \mathrm{Al}_{2} \mathrm{O}_{3} \cdot 6 \mathrm{H}_{2} \mathrm{O}$ and $3 \mathrm{CaO} \cdot \mathrm{Fe}_{2} \mathrm{O}_{3} \cdot 6 \mathrm{H}_{2} \mathrm{O}$. Thus it is seen that the cell size of the latter will be $12.56 \mathrm{~A}$ (the size of $3 \mathrm{CaO} . \mathrm{Al}_{2} \mathrm{O}_{3}$. $6 \mathrm{H}_{2} \mathrm{O}$ ) plus $0.18 \mathrm{~A}$ or $12.74 \mathrm{~A}$. The same cube size for $3 \mathrm{CaO}$. $\mathrm{Fe}_{2} \mathrm{O}_{3} \cdot 6 \mathrm{H}_{2} \mathrm{O}$ is arrived at by considering the increase in size found to result from the complete replacement of $3 \mathrm{SiO}_{2}$ by $6 \mathrm{H}_{2} \mathrm{O}$ in these struc- 
tures. It was found to be 0.72. Therefore, the cell size of $3 \mathrm{CaO} \cdot \mathrm{Fe}_{2} \mathrm{O}_{3}$. $6 \mathrm{H}_{2} \mathrm{O}$ will equal $12.02 \mathrm{~A}$ (the cell size for $3 \mathrm{CaO} . \mathrm{Fe}_{2} \mathrm{O}_{3} \cdot 3 \mathrm{SiO}_{2}$ ) plus 0.72 or $12.74 \mathrm{~A}$.

As has been explained elsewhere in this paper, it is difficult to prepare pure lime ferrite hydrate. It tends to take up silica from the container during preparation and appears to be unstable when silica is not present. One product, (No. 10), had a cell size of 12.74 A. While this sample contained a small amount of silica, it also had an excess of CaO. Possibly the silica was not in the hydrate structure but was combined with the extra $\mathrm{CaO}$. A pattern of this sample is given in table 10. The cell size of $3 \mathrm{CaO} \cdot \mathrm{Fe}_{2} \mathrm{O}_{3} \cdot 6 \mathrm{H}_{2} \mathrm{O}$ is therefore believed to be near $12.74 \mathrm{~A}$. Eiger [1] reported the cell size to be $12.71 \mathrm{~A}$, stating that silica was present in his product. It is probable, therefore, that the cell size reported by him is smaller than that of the pure hydrate.

\section{TABLE 10.-Interplanar spacing and estimated relative intensities for $3 \mathrm{CaO} . \mathrm{Fe}_{2} \mathrm{O}_{3} .6 \mathrm{H}_{2} \mathrm{O}$ \\ $[a=12.74 \pm 0.02 \mathrm{~A}]$}

[ $V S=$ very strong; $V W=$ very weak; $M=$ medium; $S=$ strong; $W=$ weak]

\begin{tabular}{|c|c|c|}
\hline$h \mathrm{kl}$ & $d$ & $\begin{array}{l}\text { Estimated } \\
\text { intensity }\end{array}$ \\
\hline $\begin{array}{c}211 \\
220 \\
321 \\
\text { 달. } 400 \\
420 \\
332 \\
422 \\
431 \\
7321 \\
611-532 \\
541 \\
631 \\
543 \\
640 \\
721-633-532 \\
642 \\
732-651 \\
800 \\
822-660 \\
840 \\
842\end{array}$ & $\begin{array}{l}5.20 \\
4.54 \\
3.40 \\
3.19 \\
2.85 \\
2.72 \\
2.60 \\
2.50 \\
2.326 \\
2.069 \\
1.988 \\
1.881 \\
1.801 \\
1.766 \\
1.728 \\
1.702 \\
1.615 \\
1.590 \\
1.500 \\
1.425 \\
1.391\end{array}$ & $\begin{array}{l}M \\
S \\
W \\
S \\
S \\
V W \\
M \\
V W \\
M \\
M \\
W \\
V W \\
V W \\
M \\
W \\
V S \\
V W \\
W \\
W \\
M \\
V W\end{array}$ \\
\hline
\end{tabular}

Table 9 gives unit-cell sizes of various compositions in this series, all being intermediate between the cell sizes of the end members. Figure 7 shows the relation of cell size to composition.

\section{OCCURRENCE OF THE SERIES AS NATURAL MINERALS}

The only compound in the series, besides the anhydrous garnets, known to occur as a natural mineral is plazolite $\left(3 \mathrm{CaO} \cdot \mathrm{Al}_{2} \mathrm{O}_{3} \cdot 2 \mathrm{SiO}_{2}\right.$. $2 \mathrm{H}_{2} \mathrm{O}$ ) [7]. The crystal structure of this mineral was studied by Pabst [18], who found plazolite to have a unit cube of $12.14 \mathrm{~A}$ and to have atomic position in $\mathrm{O}_{h}^{10}$ similar to garnet.

Previously plazolite has been reported only from Crestmore, California. In this laboratory it has been identified in massive hillebrandite from Velardena, Durango, Mexico. 


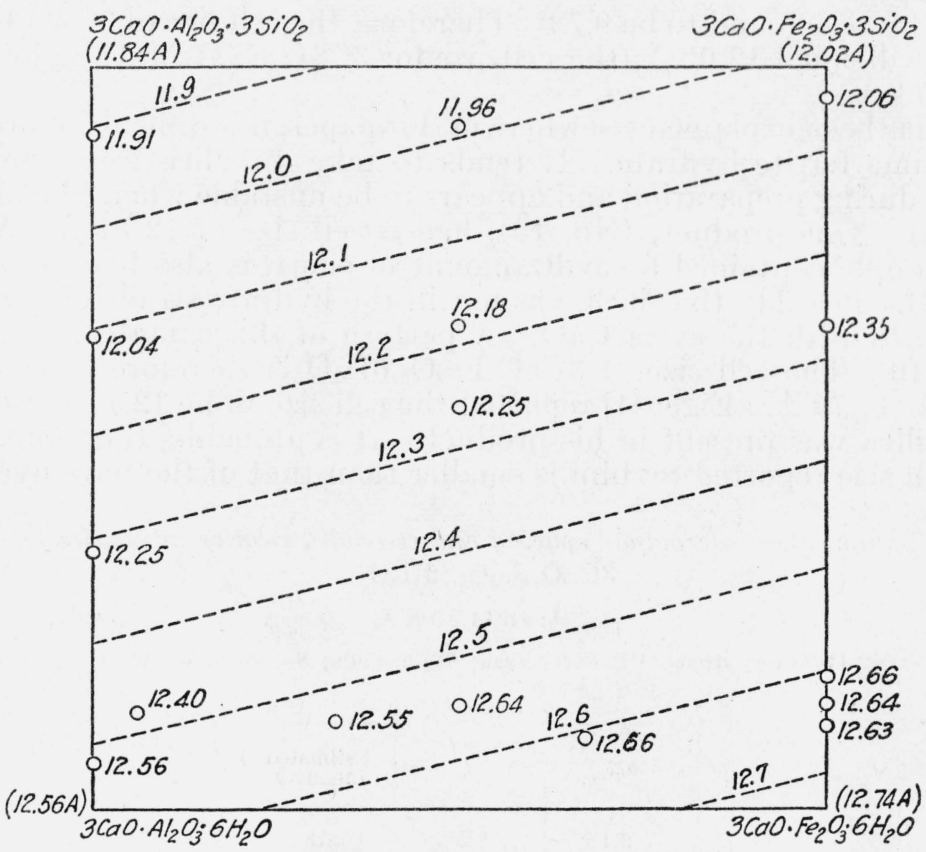

FIGURE 7.-Variation in unit-cube size with composition in the series $3 \mathrm{CaO} . \mathrm{R}_{2} \mathrm{O}_{3} \cdot 6 \mathrm{H}_{2} \mathrm{O}-3 \mathrm{CaO} . \mathrm{R}_{2} \mathrm{O}_{3} \cdot 3 \mathrm{SiO}_{2}$.

[Mole percent basis]

The hydrothermal production of garnet in this work gives some clue to the method of its formation in rocks. Garnet is not stable at its melting point, since a melt of grossularite composition crystallizes at atmospheric pressure to anorthite, gehlenite, and wollastonite. Garnet largely occurs in metamorphic rocks where there has been great pressure and hydrothermal action may have taken place.

\section{SUMMARY OF X-RAY STUDY}

An X-ray study has confirmed the existence of an isomorphous series between the four compounds:

$$
\begin{aligned}
& 3 \mathrm{CaO} \cdot \mathrm{Al}_{2} \mathrm{O}_{3} \cdot 6 \mathrm{H}_{2} \mathrm{O} \text {, } \\
& 3 \mathrm{CaO} \cdot \mathrm{Fe}_{2} \mathrm{O}_{3} \cdot 6 \mathrm{H}_{2} \mathrm{O} \text {, } \\
& 3 \mathrm{CaO} \cdot \mathrm{Al}_{2} \mathrm{O}_{3} \cdot 3 \mathrm{SiO}_{2} \text {, and } \\
& 3 \mathrm{CaO} \cdot \mathrm{Fe}_{2} \mathrm{O}_{3} \cdot 3 \mathrm{SiO}_{2} \text {. }
\end{aligned}
$$

These compounds are all cubic and are in the space group $\mathrm{O}_{h}^{10}$, with eight molecules in the unit cell. The cube size varies from $11.84 \mathrm{~A}$ to $12.74 \mathrm{~A}$. In this series, six molecules of $\mathrm{H}_{2} \mathrm{O}$ are interchangeable with three molecules of $\mathrm{SiO}_{2}$. The replacement of $\mathrm{SiO}_{2}$ by $\mathrm{H}_{2} \mathrm{O}$ is accompanied by an increase in cube size of $0.72 \mathrm{~A}$. A replacement of $\mathrm{Al}_{2} \mathrm{O}_{3}$ by $\mathrm{Fe}_{2} \mathrm{O}_{3}$ results in an increased cell size of $0.18 \mathrm{~A}$.

The atomic positions in $\mathrm{O}_{h}^{10}$ for $3 \mathrm{CaO} \cdot \mathrm{Al}_{2} \mathrm{O}_{3} \cdot 6 \mathrm{H}_{2} \mathrm{O}$ are as follows:

$$
\begin{aligned}
& 16 \mathrm{Al} \text { in } 16 a\left(\begin{array}{lll}
0 & 0 & 0
\end{array}\right) \\
& 24 \mathrm{Ca} \text { in } 24 e(1 / 41 / 80) \\
& 96 \mathrm{O} \text { in } 96 h(x, y, z) \text {, }
\end{aligned}
$$

with $x=0.025, y=0.05$, and $z=0.64$. 


\section{REFERENCES}

[1] A. Eiger, Rev. matériaux construction trav. publics, 33, 141-2 (1937).

[2] W. Lerch and L. T. Brownmiller, J. Research NBS 18, 609-22 (1937) RP997.

[3] E. P. Flint, H. F. McMurdie, and L. S. Wells, J. Research NBS 21, 617-38 (1938) RP1147.

[4] L. S. Wells, BS J. Research 1, 951-1009 (1928) RP34.

[5] T. Thorvaldson and N. S. Grace, Can. J. Research 1, 36-47 (1929).

C. W. R. Mylius, Acta Acad. Aboensis, Math. et Phys. 7, 3 (1933).

[6] E. Brandenberger, Schweiz. mineralog. petrog. Mitt. 13, 569-70 (1933).

[7] W. F. Foshag, Am. Mineral. 5, 183-85 (1920).

[8] W. F. Foshag, Am. Mineral. 9, 94 (1924).

[9] N. H. and A. N. Winchell, Elements of Optical Mineralogy, part 2, 3d ed. p. 183 (John Wiley \& Sons, New York, N. Y., 1931).

[10] W. E. Ford, Am. J. Sci. [4] 40, 33-49 (1915). M. Fleischer, Am. Mineral. 2R, 751-59 (1937).

[11] W. Lerch and R. H. Bogue, Ind. Eng. Chem. 26, 837-47 (1934).

[12] D. T. Mather and T. Thorvaldson, Can. J. Research 15, B, 331-39 (1937).

[13] W. Büssem, Proc. of the Symposium on the Chemistry of Cements, Stockholm, 1938, p. 163, 497-98. (Ingeniörsvetenskapsakademien, Stockholm, 1938.)

[14] F. M. Lea, Proc. of the Symposium on the Chemistry of Cements, Stockholm, 1938, p. 475. F. M. Lea and C. H. Desch, The Chemistry of Cement and Concrete, p. 267. (Edwin Arnold \& Co., London, 1935.)

[15] G. Menzer, Z. Krist. 63, 157 (1926).

[16] International Tables for the Determination of Crystal Structures (Gebr. Borntraeger, Berlin, 1935).

[17] R. W. G. Wyckoff, The Structure of Crystals, 2d ed. (Chemical Catalog Co., New York, N. Y., 1931).

[18] A. Pabst, Am. Mineral. 22, 861, (1937).

Washington, October 22, 1940. 